\title{
1 Calcium Isotopes in Deep Time: Potential and Limitations
}

2

3 Nikolaus Gussone ${ }^{\mathrm{a}}$, Anne-Sofie C. Ahm ${ }^{\mathrm{b}}$, Kimberly V. Lau ${ }^{\mathrm{c}}$, Harold J. Bradbury ${ }^{\mathrm{d}}$

4

5

a Institut für Mineralogie, Universität Münster, Corrensstraße 24, D-48149 Münster, Germany

${ }^{\mathrm{b}}$ Department of Geosciences, Princeton University, Guyot Hall, Princeton, New Jersey, USA

${ }^{c}$ Department of Geology and Geophysics, University of Wyoming, Laramie, Wyoming, USA

${ }^{\mathrm{d}}$ Department of Earth Sciences, University of Cambridge, Cambridge, UK

\section{Abstract}

Calcium is an essential element in the biogeochemical cycles that regulate the long-term climate state of Earth. The removal of $\mathrm{CO}_{2}$ from the ocean-atmosphere system is controlled by the burial of carbonate sediments $\left(\mathrm{CaCO}_{3}\right)$, ultimately linking the global calcium and carbon cycles. This fundamental link has driven the development of the stable calcium isotope proxy with application to both ancient skeletal and non-skeletal bulk carbonate sediments. Calcium isotope ratios $\left(\delta^{44 / 40} \mathrm{Ca}\right)$ have been used to track long-term changes in seawater chemistry (e.g., aragonite vs. calcite seas) and to elucidate short-term climatic perturbations associated with mass extinction events. However, developments in the calcium isotope proxy have shown that $\delta^{44 / 40} \mathrm{Ca}$ values in carbonate minerals also are sensitive to changes in precipitation rates, mineralogy and diagenesis, thereby complicating the application of the proxy to the reconstruction of global cycles. First, inorganic carbonate precipitation experiments have demonstrated that carbonate $\delta^{44 / 40} \mathrm{Ca}$ values are sensitive to precipitation rates with higher rates generally leading to larger fractionation. Second, $\delta^{44 / 40} \mathrm{Ca}$ values are sensitive to carbonate mineralogy with inorganic aragonite and calcite being on average $\sim 1.5 \%$ and $\sim 0.9 \%$ depleted relative to contemporaneous seawater, respectively. The effects of both changes in carbonate mineralogy and precipitation rates affect primary and secondary minerals, but are particularly pronounced during 
carbonate diagenesis where relatively slow rates of recrystallization and neomorphism can lead to significant changes in bulk sediment $\delta^{44 / 40} \mathrm{Ca}$ values. Third, changes in faunal composition expressed in skeletal fossil archives can lead to large changes in carbonate $\delta^{44 / 40} \mathrm{Ca}$ values that are decoupled from changes in global cycles. Nevertheless, when these factors are appropriately considered the application of calcium isotopes in ancient carbonate sediments becomes a powerful tool for understanding biogeochemical processes that operate over many scales; from diagenetic changes within the sediment pore-space, to regional changes across ancient carbonate platforms, and to global changes in seawater chemistry through time. Importantly, the processes that contribute to variability in carbonate $\delta^{44 / 40} \mathrm{Ca}$ values are likely to impact other carbonatebound proxies, highlighting the potential for calcium isotopes as a hint to better understand the variability of other isotope systems.

\section{Highlights:}

- carbonate $\delta^{44} \mathrm{Ca}$ records provide valuable information about Earth's past surface environments

- carbonate $\delta^{44} \mathrm{Ca}$ records should be interpreted in the context of the specific archive and its geological history

- $\delta^{44} \mathrm{Ca}$ records can be driven by changes in input/output flux, fractionation factor during carbonate formation and diagenesis

- primary $\delta^{44} \mathrm{Ca}_{\text {archive }}$ affected by stoichiometry, mineralogy, kinetic isotope effects during primary carbonate formation and faunal composition

- after over two decades of Ca isotope research, fundamental questions are still unresolved 
51 Ca isotopes; $\delta^{44} \mathrm{Ca} ; \delta^{44 / 40} \mathrm{Ca} ; \delta^{44 / 42} \mathrm{Ca}$; paleo-environment; geochemical cycling; Earth history; diagenesis; proxy

1 Introduction

Variations in the $\mathrm{Ca}$ isotope composition of rocks, minerals, fossils, soils and fluids have attracted the interest of researchers since the origins of mass spectrometry. As a major constituent in magmatic, metamorphic and sedimentary rocks, $\mathrm{Ca}$ is involved in the global cycling of rocks; it plays an important role during melting and crystallization, metamorphism and metasomatism, authigenesis and recrystallization, as well as rock alteration and weathering. In addition, $\mathrm{Ca}$ plays an important role in the metabolic pathways of organisms and as a stoichiometric component of numerous biominerals. In particular, the mass production of $\mathrm{CaCO}_{3}$ in the ocean promate state on Earth.

Calcium isotope ratios have been used to identify sources and quantify budgets in geochemical cycles on various spatial and temporal scales, ranging from molecular to solar system processes and from seconds to billions of years. Calcium has six stable or extremely long-lived isotopes $\left({ }^{40} \mathrm{Ca}\right.$ to $\left.{ }^{48} \mathrm{Ca}\right)$, spanning a relative mass-difference of $20 \%$ (e.g. Haynes et al., 2017) and massdependent fractionation between these isotopes can be induced by chemical, physical and biological processes. During the last two decades, the increased precision and accuracy of analytical techniques has resulted in greater resolution of natural isotopic variability and contributed to an increased understanding of mass-dependent $\mathrm{Ca}$ isotope systematics. In particular, highprecision records can reveal small scale $\mathrm{Ca}$ isotope fluctuations in deep time-records, which may not be resolved in less precise data. These seemingly discrepant results can further lead to different concepts of mechanisms, governing $\mathrm{Ca}$ isotope fractionation on global and or local scale. Nevertheless, a comparison of different analytical approaches is not within the scope of 
this contribution, as a separate article within this special issue is dedicated to the development of analytical methods (Chakrabarti et al., this issue) and consequently not further discussed here.

In the literature, mass dependent differences of $\mathrm{Ca}$ isotope ratios are mostly reported as ${ }^{44} \mathrm{Ca} /{ }^{40} \mathrm{Ca}$ or ${ }^{44} \mathrm{Ca} /{ }^{42} \mathrm{Ca}$ ratios, expressed as either $\delta^{44 / 40} \mathrm{Ca} \quad[\%]=\left(\left({ }^{44} \mathrm{Ca} /{ }^{40} \mathrm{Ca}\right)_{\text {sam }}\right.$ ple $\left./\left({ }^{44} \mathrm{Ca} /{ }^{40} \mathrm{Ca}\right)_{\text {standard }}-1\right) \cdot 1000$ or $\delta^{44 / 42} \mathrm{Ca}[\%]=\left(\left({ }^{44} \mathrm{Ca} /{ }^{42} \mathrm{Ca}\right)_{\text {sample }} /\left({ }^{44} \mathrm{Ca} /{ }^{42} \mathrm{Ca}\right)_{\text {standard }}-1\right) \cdot 1000$, respectively. Because of the different relative mass differences between ${ }^{44} \mathrm{Ca}$ and ${ }^{40} \mathrm{Ca}$ or ${ }^{44} \mathrm{Ca}$ and ${ }^{42} \mathrm{Ca}, \delta^{44 / 40} \mathrm{Ca}$ and $\delta^{44 / 42} \mathrm{Ca}$ differ from each other. The relation between both $\delta$-values differs, if kinetic or equilibrium isotope fractionation is assumed. For kinetic isotope fractionation the conversion follows $\delta^{44 / 40} \mathrm{Ca}=\delta^{44 / 42} \mathrm{Ca} \cdot\left(\ln \left(\mathrm{m}^{44} \mathrm{Ca} / \mathrm{m}^{40} \mathrm{Ca}\right)\right) /\left(\ln \left(\mathrm{m}^{44} \mathrm{Ca} / \mathrm{m}^{42} \mathrm{Ca}\right)\right)$ and can be approximated by $\delta^{44 / 40} \mathrm{Ca}[\% 0]=\delta^{44 / 42} \mathrm{Ca} \cdot 2.05$, and for equilibrium isotope fractionation $\delta^{44 / 40} \mathrm{Ca}=\delta^{44 / 42} \mathrm{Ca} \cdot\left(1 / \mathrm{m}^{44} \mathrm{Ca}-1 / \mathrm{m}^{40} \mathrm{Ca}\right) /\left(1 / \mathrm{m}^{44} \mathrm{Ca}-1 / \mathrm{m}^{42} \mathrm{Ca}\right)$, which can be approximated by $\delta^{44 / 40} \mathrm{Ca}[\%]=\delta^{44 / 42} \mathrm{Ca} \cdot 2.10$, with $\mathrm{m}^{\mathrm{x}} \mathrm{Ca}$ being the exact atomic masses of the respective $\mathrm{Ca}$ isotopes (e.g. Heuser et al. 2016). In addition, it should be noted that there is currently no consensus on the normalizing standards for Ca isotope $\delta$ values. However, based on recommendations of the IUPAC (Coplen et al., 2002), most studies report Ca isotope data either relative to SRM 915a or to modern seawater, with seawater being $+1.88 \%{ }_{0}\left(\delta^{44 / 40} \mathrm{Ca}\right)$ and $0.92 \% 0\left(\delta^{44 / 42} \mathrm{Ca}\right)$ relative to SRM 915a (e.g., Heuser et al., 2016). Here, we report data as $\delta^{44 / 40} \mathrm{Ca}$ relative to SRM 915a.

Early $\mathrm{Ca}$ isotope research focused on processes taking place early in Earth history and the solar system. Favoured topics included high temperature processes, such as mass-dependent isotope fractionation during condensation and evaporation, nucleosynthetic anomalies and the branched ${ }^{40} \mathrm{~K}$ decay to ${ }^{40} \mathrm{Ar}$ and ${ }^{40} \mathrm{Ca}$. For example, early research investigated the $\mathrm{Ca}$ isotope variability of the oldest preserved components formed in the solar system (Ca-aluminium-rich inclusions), radiogenic ${ }^{40} \mathrm{Ca}$ signatures in ancient magmatic rocks and age dating of old terrestrial and lunar 
rocks (e.g., Bermingham et al., 2018; Kreissig and Elliott, 2005; Marshall and DePaolo, 1989; Russell et al., 1978; Shih et al., 1993; Antonelli et al., this issue; Valdes et al., this issue, this issue).

The consequences of mass-dependent $\mathrm{Ca}$ isotope fractionation for low temperature processes have focused on reconstruction of paleo-environments and geochemical cycling of $\mathrm{Ca}$ through time. In the low temperature environment, the coupling between $\mathrm{Ca}$ and carbonate has received special attention, ultimately connecting $\mathrm{Ca}$ with the global $\mathrm{C}$ cycle and climate. Consequently, a large proportion of studies dealing with $\mathrm{Ca}$ isotopes are directly or indirectly aimed at constraining oceanic $\mathrm{Ca}-\mathrm{C}$ cycling. This link has mainly been explored through paleo-seawater reconstructions of $\mathrm{Ca}$ isotope ratios and $\mathrm{Ca}$ budget modelling that is constrained by estimates of sources and sinks from the modern (see Section 1.2). In addition to the link with $\mathrm{C}$ cycling, $\mathrm{Ca}$ isotopes can contribute to a better understanding of sulphate and phosphate cycling, for example, in evaporitic basins and upon formation of phosphorite deposits (Blättler and Higgins, 2014; Soudry et al., 2006).

The focus of this article is to discuss the potential and challenges of using $\mathrm{Ca}$ isotopes to study Ca cycling throughout Earth history. We highlight how increasing understanding of processes that fractionate $\mathrm{Ca}$ isotopes has led to a re-examination of existing approaches and the development of new concepts. The intention of this article is not to produce a fixed recipe to generate Ca isotope records in deep time. Rather, we encourage the reader to reconsider and validate basic assumptions, potential influencing parameters and model prerequisites for the respective regional setting, sedimentary facies and investigated time period. The continuing evaluation of fundamental assumptions and model parameters is required for future developments in Ca isotope research. The newly gained or refined knowledge on $\mathrm{Ca}$ isotope fractionation processes or characteristics of Earth's reservoirs point to both potentials for novel applications and to 
complications for established approaches, which need to be taken into account for meaningful reconstructions.

In this paper, we review methods of tracking $\mathrm{Ca}$ isotope evolution through Earth history by modelling the oceanic $\mathrm{Ca}$ isotope budget, based on different archives (e.g., biominerals, bulk carbonate, phosphate, gypsum and barite). We discuss the methods, assumptions, and issues associated with each technique, and then provide an overview of the published Ca isotope records. Finally, we discuss the potential of Ca isotope ratios, through these methods, for providing new insights into seawater $\mathrm{Ca}$ isotope variations, carbonate diagenesis and mineralogy.

\section{Global Ca cycling throughout Earth history}

\subsection{The oceanic $\mathrm{Ca}$ isotope budget}

When interpreting the $\mathrm{Ca}$ isotope record in deep time, the original goal was to reconstruct the ocean budget of $\mathrm{Ca}$, in order to quantify global changes in the input and output fluxes. One of the major tools for interpreting changes in the global Ca cycle through deep time is the use of a box model. Calcium concentration and isotope box models have been used to reconstruct the modern oceanic Ca budget in a range of studies (e.g., De La Rocha and DePaolo, 2000; Fantle and Tipper, 2014; Heuser et al., 2005; Schmitt et al., 2003; Tipper et al., 2010; Zhu and Macdougall, 1998). A box model simulates the response of the system to changes in the fluxes and isotopic composition of inputs and outputs. The basic principle for a simple box model is that the total quantity of the element of interest (in this case $\mathrm{Ca}$ : $\mathrm{M}_{\mathrm{Ca}}$ ) within the box is dependent on the sum of the fluxes of the inputs $\left(F_{\text {inputs }}\right)$ and outputs $\left(F_{\text {outputs }}\right)$.

$$
\frac{d M_{C a}}{d t}=\sum_{\text {inputs }} F_{\text {inputs }}-\sum_{\text {outputs }} F_{\text {outputs }}
$$


Modern seawater Ca concentrations are $\sim 10 \mathrm{mmol} / \mathrm{kg}$ and indicate an estimated residence time of $1.1 \times 10^{6}$ years (Broecker and Peng, 1982), significantly longer than the ocean mixing time.

149 Consequently, $\mathrm{Ca}$ concentrations and isotope ratios are likely homogenous throughout the ocean (Zhu and Macdougall, 1998), because carbonate precipitation in shallow water and dissolution at depth is not sufficiently large compared to the Ca inventory to create a significant isotope gradient in the ocean.

The addition of isotopes to Eqn. 1 adds an extra degree of complexity and allows for a tighter constraint to be placed upon the system (Eqn. 2).

$M_{C a} \frac{d \delta_{S W}}{d t}=\sum F_{\text {inputs }}\left(\delta_{\text {inputs }}-\delta_{S W}\right)-\sum F_{\text {output }} \Delta_{\text {sed }}$ Equation 2

where $\delta_{S W}$ refers to the isotopic composition of seawater. $\delta_{\text {inputs }}$ is the isotopic compositions of the input flux from the ocean, and the isotopic offset for the outputs is expressed as $\Delta_{\text {sed, }}$, representing the average fractionation factor on the formation of the calcium-bearing minerals relative to seawater (see Section 2.2).

Box modelling is addressed in greater detail by Druhan et al. (2020) in this issue. Using Equations 1 and 2, it is possible to evaluate the impact on the Ca seawater reservoir and isotope composition from changes in the $F_{\text {inputs }}$ through the weathering of carbonate and silicate rocks, and from changes in the $F_{\text {outputs }}$ through transient perturbations to carbonate burial. Similarly, changes in both $\delta_{\text {inputs }}$ and in the fractionation factor of the outputs $\left(\Delta_{\text {sed }}\right)$ can also be evaluated. However, to accurately predict the response to seawater $\delta^{44 / 40} \mathrm{Ca}$ values from transient perturbations in the oceanic $\mathrm{Ca}$ budget, carbonate precipitation (and hence, $F_{\text {outputs }}$ ) must be tied to alkalinity and coupled to similar mass balance equations for the oceanic $\mathrm{C}$ budget through carbonate weathering and the precipitation of carbonate from the ocean (e.g., Komar and Zeebe, 2016). 
$\frac{\sum F_{\text {outputs }}}{\sum F_{\text {inputs }}}=\frac{1}{\Delta_{\text {sed }}}\left[\frac{M_{C a}}{\sum F_{\text {inputs }}} \frac{d \delta_{S W}}{d t}+\left(\delta_{\text {inputs }}-\delta_{S W}\right)\right]$ Gussone and Friedrich, 2018). approaches.

\subsection{Signatures and fluxes of oceanic Ca sources} their uncertainties can affect $\mathrm{Ca}$ budget reconstruction.

To investigate changes in the ratio of the input to output flux as a function of Ca isotope seawater changes, Equation 2 can be rearranged to Equation 3 (Fantle and DePaolo, 2005).

Equation 3 highlights the factors that impact the calculated ratio of the inputs and outputs $\left(\Sigma \mathrm{F}_{\text {out- }}\right.$ puts $\left./ \Sigma F_{\text {inputs }}\right)$ of the system. These include, besides the isotopic characterizations of Ca sources and sinks and the quality of $\delta_{\mathrm{SW}}$ reconstructions, the assumed residence time $\left(\mathrm{M}_{\mathrm{Ca}} / \Sigma \mathrm{F}_{\text {inputs }}\right)(\mathrm{e} . \mathrm{g}$.,

The following sections discuss the sources and sinks for the oceanic $\mathrm{Ca}$ budget and the uncertainties associated with them. Due to the variety of necessary assumptions, it is the uncertainties related to the fluxes and isotopic compositions that limits the potential of simple box model

The reconstruction of the oceanic $\mathrm{Ca}$ budget through time is challenging and requires a detailed understanding of the Ca content and isotope composition of the involved sources and isotope fractionation mechanisms occurring along all major Ca transport paths. While our understanding of the modern $\mathrm{Ca}$ cycle has increased, there are still uncertainties and unknowns in both sources and sinks (Griffith et al., this issue) and it is uncertain to what degree modern estimates can be extended into the past. Below, we highlight the most important sources and discuss how

At present, the $\mathrm{Ca}$ input to the ocean is dominated by three main $\mathrm{Ca}$ sources, hydrothermal input, riverine runoff, and submarine groundwater discharge (Fig. 1). While the relative size of these $\mathrm{Ca}$ input fluxes is still uncertain, the isotopic composition of riverine and hydrothermal 
inputs is relatively well defined with average $\delta^{44 / 40} \mathrm{Ca}$ values of $\sim 0.9 \%$ and $0.64 \%$, respectively (e.g., Amini et al., 2008; Fantle and Tipper, 2014; Tipper et al., 2016). Although rivers that drain basaltic terrains can be dominated by weathering of hydrothermal calcite with higher $\delta^{44 / 40} \mathrm{Ca}$ values (e.g., Jacobson et al., 2015; Moore et al., 2013). The isotopic composition of groundwater and spring waters is less constrained and shows significant variability ranging from 0.2 to 2.1\%o (e.g., Holmden et al., 2012; Shao et al., 2018; Tipper et al., 2016).

Given the relatively small isotopic difference between input fluxes (e.g., 0.2-0.3\%o difference between hydrothermal and riverine $\mathrm{Ca}$ input), estimating the contribution of the different $\mathrm{Ca}$ sources during past times presents a major challenge. A strategy to approximate the ratio of continental to hydrothermal input of $\mathrm{Ca}$ includes the coupling of $\delta^{44 / 40} \mathrm{Ca}$ records with inferred seawater ${ }^{87} \mathrm{Sr} /{ }^{86} \mathrm{Sr}$ (e.g., McArthur et al., 2001) and $\mathrm{Mg} / \mathrm{Ca}$ (e.g., Hardie, 1996) ratios through time (Wang et al., 2019). However, currently there are no proxies to distinguish between past groundwater and riverine inputs. Furthermore, the flux of $\mathrm{Ca}$ from groundwater discharge may have varied significantly through time and space and between glacial and interglacial periods, complicating its proper implementation into models (e.g., Milliman, 1993).

A further source of isotopically light $\mathrm{Ca}$ that has been proposed is a flux of diagenetic fluids into the ocean (e.g., Fantle and Higgins, 2014; Sun et al., 2016). The basic principle of the hypothesis is that during recrystallization, the primary low $\delta^{44 / 40} \mathrm{Ca}$ values of the biogenic carbonates are increased leading to a mobilisation of isotopically light $\mathrm{Ca}$ which can potentially be released into the open ocean. This flux may have been more important prior to the evolution of pelagic skeletal carbonates in the Mid-Mesozoic (Ridgwell and Zeebe, 2005), where carbonate deposition was concentrated in shallow-water platforms. The contribution of this source to the global Ca cycle is however unconstrained yet.

In addition to the relative proportion of the fluxes, the $\delta^{44 / 40} \mathrm{Ca}$ value of the continental input may have changed through time. For example, the isotopic composition of the exposed rocks, 
the evolution of crust, and the fractionation of $\mathrm{Ca}$ isotopes on the continents may have been temporally variable. The last mechanism is demonstrated by an offset $(\sim 0.2 \%)$ between the average $\delta^{44 / 40} \mathrm{Ca}$ of rivers and weathered rocks (e.g., Tipper et al., 2006, Fantle and Tipper, 2014; Tipper et al., 2016). The higher riverine $\delta^{44 / 40} \mathrm{Ca}$ values suggests an actively growing ${ }^{40} \mathrm{Ca}$-enriched continental $\mathrm{Ca}$ reservoir, composed of vegetation, secondary minerals and/or an exchangeable Ca pool (e.g., Tipper et al., 2016). Although little is known about the development of the continental reservoir over time and the degree of which a steady-state has been reached (if it evolved steadily, or if phases of growth were interrupted by phases of decay), it is likely that before its establishment, continental runoff was less fractionated relative to the exposed continental crust. In addition, in the early eons of Earth history, other transport processes, such as dust transport (Fantle et al., 2012, Ewing et al., 2008), may have played more important roles than today. However, a recent compilation of $\delta^{44 / 40} \mathrm{Ca}$ values from Precambrian carbonate rocks indicates that the long-term $\mathrm{Ca}$ input flux had a near-constant isotopic composition equal to the value of bulk silicate earth (Blättler and Higgins, 2017). While independent constraints for some parameters exist (e.g., hydrothermal input), other parameters are still poorly constrained. Strategies to cope with these complications could include the development of independent proxies to track changes in groundwater input, diagenetic flux and the evolution of the continental $\mathrm{Ca}$ reservoir. Before such proxies are established, $\mathrm{Ca}$ isotope budget reconstructions require a critical assessment of known and unknown input parameters and their associated uncertainties, leading to a full discussion of how the unconstrained parameters may affect the isotope record.

2.3 Isotope fractionation during deposition of oceanic $\mathrm{Ca}$ sinks and formation of archives

Marine carbonate sediments are the dominant sink for $\mathrm{Ca}$ from the ocean and are on average 1\%o lighter than seawater (Fig. 2). It was originally debated whether this fractionation is 
constant or dependent on temperature, and consequently, if variations in the $\delta^{44 / 40} \mathrm{Ca}$ record reflect changes in the Ca budget or paleo-temperatures (e.g., Nägler et al., 2000; Skulan et al., 1997). Although it is now established that Ca isotopes have little sensitivity to temperature (generally $<0.03 \%$ o $/{ }^{\circ} \mathrm{C}$, e.g., compilation in Gussone and Heuser, 2016), this initial debate initiated a series of detailed calibration studies. These studies identified parameters that influence $\mathrm{Ca}$ isotope fractionation in inorganic mineral phases and in biogenic minerals, including species-specific Ca isotope fractionation (e.g., Böhm et al., 2006; Gussone et al., 2003; Lemarchand et al., 2004; Marriott et al., 2004; Sime et al., 2005). One of the major finding from these studies was that $\mathrm{CaCO}_{3}$ mineralogy has a large effect on the fractionation (Gussone et al., 2005) and must be taken into account when interpreting and modelling $\mathrm{Ca}$ isotope records of the past (Fig. 2). Moreover, these studies showed that $\mathrm{Ca}$ isotopes values in inorganic carbonates are especially sensitive to mineral precipitation rates with important implications for the future application of this proxy (Lemarchand et al., 2004; Nielsen et al., 2012; Tang et al., 2008b).

Due to the complications of both mineralogy and precipitation rates, the biomineral record plays a critical role in reconstructing changes in the Ca budget of the recent past and for defining $\Delta_{\text {sed }}$ (the average $\mathrm{Ca}$ isotope fractionation between seawater and oceanic $\mathrm{Ca}$ sink). Additionally, $\mathrm{Ca}$ isotope systematics of inorganic and biogenically induced carbonate minerals are important to study ancient oceans, evaporitic basins, and diagenesis. Here, we summarize Ca isotope fractionation in both inorganic and biogenic carbonates.

\subsubsection{Inorganic mineral phases}

The physico-chemical processes that control $\mathrm{Ca}$ isotope fractionation during inorganic mineral precipitation have been investigated with precipitation experiments and modelling studies (e.g., 
Ca isotope fractionation between crystal and fluid $\left(\Delta^{44 / 40} \mathrm{Ca}\right)$ observed in natural and synthetic mineral phases is the result of thermodynamic, kinetic and/or disequilibrium isotope effects. Equilibrium isotope fractionation is controlled by the difference in $\mathrm{Ca}$ bond strength between the solid phase and the fluid. In general, the heavy isotopes (i.e. ${ }^{44} \mathrm{Ca}$ ) are enriched in the stronger bonds. This relationship is expressed by an inverse relationship between $\Delta^{44 / 40} \mathrm{Ca}$ and crystal Ca coordination, where lower coordination numbers are associated with shorter and stronger bonds, and has been observed in carbonates, sulphates and phosphates (e.g., Colla et al., 2013; Griffith et al., 2008b; Gussone et al., 2011, 2005; Harouaka, 2011; Hensley, 2006) as well as silicate minerals (e.g. Ryu et al. 2011, Huang et al. 2010). However, there are deviations from this general trend that may be related to the fact that the $\mathrm{Ca}-\mathrm{O}$ bond strength in the minerals depend not only on the $\mathrm{Ca}$ coordination but also on other factors, i.e. Ca isotope fractionation between mineral and dissolved $\mathrm{Ca}$ depends not only on the $\mathrm{Ca}$ bonds in the solid, but also on the speciation of Ca in the fluids (Colla et al., 2013, Moynier and Fujii, 2017).

The variability in $\Delta^{44 / 40} \mathrm{Ca}$ of a single phase, such as the range of $\sim 2 \%$ for calcite formed at different conditions (Fig. 2), reflects kinetic isotope fractionation during mineral precipitation (e.g., Lemarchand et al., 2004; Marriott et al., 2004; Reynard et al., 2011; Tang et al., 2012). The degree of kinetic $\mathrm{Ca}$ isotope fractionation is controlled by precipitation rate and indirectly related to other factors such as the temperature-dependent speciation of carbonate ions (Lemarchand et al., 2004). In general, higher calcite saturation leads to higher precipitation rates and increased isotope fractionation (Nielsen et al., 2012). However, the saturation state can alter the relationship between precipitation rate and $\Delta^{44 / 40} \mathrm{Ca}$. A positive relationship between precipitation rate and $\Delta^{44 / 40} \mathrm{Ca}$ has been reported for experiments using highly supersaturated solutions that likely formed via a soluble meta-stable amorphous calcium carbonate (ACC) precursor phases (e.g., Lemarchand et al., 2004; Nielsen et al., 2012; Teng et al., 2017). In contrast, calcite formed at lower saturation and presumably without an ACC precursor has an inverse relationship, showing an increase in isotope fractionation with increasing precipitation rate 
(AlKhatib and Eisenhauer, 2017a; Tang et al., 2008b). Furthermore, the degree of Ca isotope fractionation also seems to depend on the stoichiometry between $\mathrm{Ca}$ and the respective anion as the availability of $\mathrm{Ca}$ determines whether kinetic or thermodynamic isotope fractionation effects dominate (Harouaka et al., 2014; Nielsen et al., 2012).

Calcite synthesis experiments demonstrate a larger variability in kinetic $\mathrm{Ca}$ isotope fractionation than the variability found in early diagenetic cements and authigenic minerals, suggesting that conditions on the seafloor are closer to equilibrium. For example, $\delta^{44 / 40} \mathrm{Ca}$ values of modern marine authigenic aragonite and ikaite are on average about $\sim 0.7 \%$ and 1.3 , respectively (Gussone et al., 2011; Teichert et al., 2005) and the $\delta^{44 / 40} \mathrm{Ca}$ values of calcite cements, and dolomites are close to the seawater value compared to the range of synthetic calcite (Fig. 2, Blättler et al., 2015; Higgins et al., 2018; Steuber and Buhl, 2006; Wang et al. 2012, 2014). Nevertheless, partly recrystallized sediments can span the range between biogenic carbonates and seawater/pore-fluid (e.g., Farkaš et al. 2016).

\subsubsection{Ca isotope fractionation in biominerals}

Biominerals are important archives recording the $\delta^{44 / 40} \mathrm{Ca}$ fluctuations of seawater throughout the Phanerozoic. Understanding $\mathrm{Ca}$ isotope fractionation during biomineral formation is of great relevance, because biogenic carbonates are the main oceanic $\mathrm{Ca}$ sink from the Phanerozoic ocean and dominantly define $\Delta_{\text {sed. }}$ As $\Delta_{\text {sed }}$ is one of the key parameters for modelling the Ca budget (see section 2.1), an understanding of the $\mathrm{Ca}$ isotope fractionation of biominerals is required to calculate paleo- $\delta^{44 / 40} \mathrm{Ca}$ seawater values through time.

Applied $\Delta_{\text {sed }}$ for a given time interval are based on estimates for the taxon- or mineral-specific Ca isotope fractionation, weighted by their global abundance in the sediments. Potential bias by preferential preservation of certain taxa or sedimentary facies (e.g., deep sea vs. shelf) and 
shifts in $\Delta_{\text {sed }}$ due to large changes in environmental conditions may need to be implemented into Ca budget modelling, but has so far not been equally considered.

Calcium isotope fractionation as a function of different environmental parameters have been studied for various taxa. This includes the main contributors to the present-day global Ca export production, namely corals (e.g., Böhm et al., 2006; Chen et al., 2016; Gothmann et al., 2016; Inoue et al., 2015), coccolithophores (e.g., Langer et al., 2007; Meija et al. 2018) and foraminifers (e.g., Griffith et al., 2008b; Gussone and Heuser, 2016; Kasemann et al., 2008; Sime et al., 2005). In addition, taxa were studied that were considered as archives for the reconstruction of $\delta^{44 / 40} \mathrm{Ca}_{\text {seawater }}$ records, such as brachiopods (e.g., Farkaš et al., 2007a; von Allmen et al., 2010), mussels (e.g., Hippler et al., 2013; Ullmann et al., 2013), ostracods (Gussone and Greifelt, 2019), sponges (Gussone et al., 2005) and dinoflagellates (Gussone et al., 2010). These calibrations revealed offsets in $\mathrm{Ca}$ isotope fractionation between taxa, demonstrating the advantages of species-specific records as a basis for oceanic Ca budget modelling (e.g., Sime et al., 2007). However, while differences in $\delta^{44 / 40} \mathrm{Ca}$ between different species, or between species and cements, present a complication they also provide the chance to monitor diagenetic alteration and provide insight into biomineralisation processes (Steuber and Buhl, 2006).

Calcium isotope fractionation is also variable within a taxon and can be dependent on several parameters related to biomineralisation and environmental factors. For instance, the typical $\sim 0.5 \% \mathrm{Ca}$ isotope difference between calcite and aragonite found in inorganic $\mathrm{CaCO}_{3}$ is not featured in all $\mathrm{CaCO}_{3}$ biominerals (Fig. 2). It is apparent in different species of sclerosponges and coralline algae (Blättler et al., 2014; Gussone et al., 2005), but it is not observed in corals and bivalves (e.g., Inoue et al. 2018; Taubner et al. 2012; Hiebenthal, 2009). The differences in fractionation are suggested to result from different cellular Ca transport pathways (Gussone et al., 2006) and can also explain the insignificant dependency of Ca isotope fractionation on environmental factors that control the growth rate (e.g., Inoue et al., 2015; Langer et al., 2007). 
While Ca isotope fractionation during inorganic mineral formation is highly dependent on precipitation rates, $\mathrm{Ca}: \mathrm{CO}_{3}$ stoichiometry, supersaturation, carbonate chemistry and salinity, these parameters have overall a relatively small impact on $\mathrm{Ca}$ isotope fractionation in corals, coccolithophores and foraminifers (e.g., Inoue et al., 2015; K1sakürek et al., 2011; Langer et al., 2007; Roberts et al., 2018). However, Ca isotope fractionation appears to be substantially reduced at low calcite saturation states in cultured coccolithophores (Gussone et al., 2007; Meija et al., 2018), a process that may also be responsible for anomalously small $\mathrm{Ca}$ isotope fractionation found in planktic and benthic foraminifers and ostracods collected from water masses with low temperatures and calcite saturation (Gussone et al. 2009; Gussone and Filipsson, 2010; Gussone et al., 2016; Gussone and Greifelt, 2019).

The effect of temperature on Ca isotope fractionation in biominerals has been heavily debated and intensively studied, but the observed substantial temperature dependence of $\sim 0.2 \%$ o $/{ }^{\circ} \mathrm{C}$ in a few taxa remains enigmatic, because large and small temperature sensitivities have been reported for the same taxa (e.g., Immenhauser et al., 2005; Nägler et al., 2000). Contrasting results have been reported for two planktic foraminifer species Globigerinoides sacculifer (culture, core top and downcore records) and Neogloboquadrina pachyderma (sinistral) (core top and plankton net samples) (e.g., Gussone et al., 2009, 2004; Heuser et al., 2005; Hippler et al., 2009, 2006; Nägler et al., 2000; Sime et al., 2005) and fossil rudists from the Cretaceous (Immenhauser et al., 2005; Steuber and Buhl, 2006). Nevertheless, the majority of taxa demonstrate temperature dependencies below $0.03 \%{ }^{\circ}{ }^{\circ} \mathrm{C}$ (e.g., Gussone and Heuser, 2016 and refs therein). These are unsuited for paleothermometry but may need to be considered if large temperature fluctuations have occurred that can lead to a measurable shift in the $\delta^{44 / 40} \mathrm{Ca}$ of the biomineral archive (Gussone and Friedrich, 2018). In the case of large global temperature changes, this

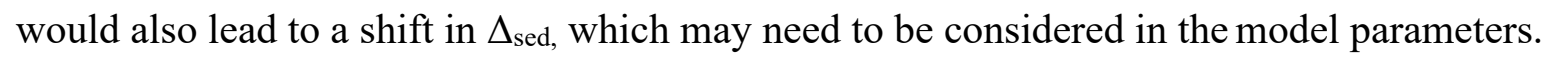


Despite the progress that has been made to understand and quantify the influence of different processes on $\mathrm{Ca}$ isotope fractionation in different minerals and taxa, there still remains open questions and observations that are discrepant with the current understanding of $\mathrm{Ca}$ isotope fractionation that are pending further investigation.

\subsection{Mass independent isotope effects}

Mass-independent isotope variability can affect the determination of stable isotope fractionation, by either contributing directly to one of the isotope masses of interest (e.g., ${ }^{40} \mathrm{Ca}$ ), or to a commonly spiked isotope mass (e.g., ${ }^{48} \mathrm{Ca}$ ). In contrast to solar system material that is not fully homogenized, nucleosynthetic anomalies are not a significant source of uncertainty for terrestrial $\mathrm{Ca}$ isotope records. However, radiogenic ${ }^{40} \mathrm{Ca}$, expressed as $\varepsilon_{\mathrm{Ca}}=\left(\left({ }^{40} \mathrm{Ca} /{ }^{44} \mathrm{Ca}\right)_{\mathrm{sam}}\right.$ ple $\left./\left({ }^{40} \mathrm{Ca} /{ }^{44} \mathrm{Ca}\right)_{\text {mantle }}-1\right) \cdot 10^{4}$ or $\varepsilon_{\mathrm{Ca}}=\left(\left({ }^{40} \mathrm{Ca} /{ }^{42} \mathrm{Ca}\right)_{\text {sample }} /\left({ }^{40} \mathrm{Ca} /{ }^{42} \mathrm{Ca}\right)_{\text {mantle }}-1\right) \cdot 10^{4}$ can build up in old terrestrial K-rich reservoirs. Radiogenic ${ }^{40} \mathrm{Ca}$ is produced from the branched decay of ${ }^{40} \mathrm{~K}$ to ${ }^{40} \mathrm{Ar}$ (electron capture) and ${ }^{40} \mathrm{Ca}\left(\beta\right.$ - decay), a branching ratio of $10.67 \%{ }^{40} \mathrm{Ar}$ and $89.33 \%$ ${ }^{40} \mathrm{Ca}$ (Nägler and Villa, 2000) and a decay constant $\lambda\left({ }^{40} \mathrm{~K}_{\beta-}\right)=4.962 \cdot 10^{-10} \cdot \mathrm{yr}^{-1}$ (Steiger and Jäger 1977). When old continental crust is weathered, it may provide a local radiogenicallyenriched ${ }^{40} \mathrm{Ca}$ source. For instance, reported $\varepsilon_{\mathrm{Ca}}$ values reach 19000 for muscovite mineral separates, 40 for bulk rocks in Archean pegmatites from the Jack Hills region (Fletcher et al., 1997), and 3 to 26 in Archean pelagic sediments (Nelson and McCulloch, 1989).

In contrast to old terrestrial reservoirs, in situ ${ }^{40} \mathrm{Ca}$ production in young $\mathrm{K}$-poor and Ca-rich reservoirs, such as carbonate sediments, is not sufficient to alter the mass-dependent $\delta^{44 / 40} \mathrm{Ca}$ signal. However, the contribution of radiogenic ${ }^{40} \mathrm{Ca}$-enriched $\mathrm{Ca}$ sources may need to be considered in special catchment areas. For example, Archean to Early Proterozoic gypsum deposits in Australia have an inherited $\varepsilon_{\mathrm{Ca}}$ signature between 2 and 6 that would translate into a bias of up to $-0.6 \%$ in $\delta$-notation (Nelson and McCulloch, 1989). Radiogenic ${ }^{40} \mathrm{Ca}$ enrichment was also 
reported for natural soils, granitic rocks and weathering experiments (e.g. Ryu et al. 2011, Farkaš et al. 2011, Marshal and DePaolo 1989). K-rich evaporite minerals are another potential source of radiogenic ${ }^{40} \mathrm{Ca}$ and contain $\varepsilon_{\mathrm{Ca}}$ values between 3 and 700 (e.g., Baardsgaard, 1987; Heumann et al., 1979).

Most studied evaporites show a lower degree of ${ }^{40} \mathrm{Ca}$ ingrowth than predicted from the $\mathrm{K} / \mathrm{Ca}$ ratio and age, implying that dating of evaporites using $\mathrm{K}-\mathrm{Ca}$ system is hindered by Ca release during salt metamorphism and recrystallization events (e.g., Baardsgaard, 1987). Similarly, Krich authigenic minerals such as sanidine and glauconite are generally less enriched in ${ }^{40} \mathrm{Ca}$ than predicted due to Ca mobilization during diagenetic reactions (Cecil and Ducea, 2011; DePaolo et al., 1983; Gopalan and Kumar, 2008). Although $\varepsilon_{\mathrm{Ca}}$ does not provide a stratigraphic age, it can reveal information about the hydrologic and thermal history of a sedimentary basin. More importantly, the observed deficits in ${ }^{40} \mathrm{Ca}$ of the $\mathrm{K}$-rich minerals demonstrate that ${ }^{40} \mathrm{Ca}$-enriched fluids are indeed mobilized during such diagenetic events and can locally act as radiogenicallyenriched Ca sources.

Potential variations in $\varepsilon_{\mathrm{Ca}}$ can complicate inferences of mass-dependent $\mathrm{Ca}$ isotope variability, but can also provide additional information that can be used to better constrain the global $\mathrm{Ca}$ cycle. For instance, it was suggested, based on the absence of significant $\varepsilon_{\mathrm{Ca}}$ variations in marine carbonates throughout the Phanerozoic that the oceanic Ca cycling is not dominated by the weathering of K-enriched continental crust and that mantle derived crustal rocks play a more important role than previously thought (Caro et al., 2010). In contrast, an offset of $1.3 \varepsilon$ units between mantle and seawater was recently described, suggesting a contribution of $10-20 \%$ hydrothermal $\mathrm{Ca}$ and 80-90\% from the upper crust (Antonelli et al., 2018).

\subsection{Behaviour of $\mathrm{Ca}$ isotopes during carbonate diagenesis}


One of the main limitations in using marine carbonate sediments to reconstruct the evolution of global biogeochemical cycles through time is the susceptibility of carbonate minerals to diagenesis. After deposition, primary carbonate sediments recrystallize and react with pore-fluids which may alter their primary chemical composition. For example, carbonate platform sediments are susceptible to early diagenesis due to significantly fluid flow from the advection (fluid-buffered) of both seawater and freshwater below the seafloor. The effects of early diagenesis in platform sediments are therefore important to constrain, in particular, prior to the evolution of pelagic skeletal carbonates in the Mid-Mesozoic where the nature and location of carbonate deposition was concentrated in shallow water platforms (Ridgwell and Zeebe, 2005). is therefore often sediment-buffered.

To avoid complications caused by carbonate diagenesis, different techniques exist to test for

Early seafloor diagenesis also takes place in pelagic sediments deposited in deeper environments, but fluid-flow rates in these settings tend to be low (diffusion dominated) and diagenesis mineralogical and diagenetic changes in carbonate sediments (e.g., petrographic microscopy, scanning electron microscopy, cathodoluminescence, X-ray diffraction and micro Raman spectroscopy) and geochemical techniques such as O or Sr isotopes (e.g. Veizer et al. 1999). While these techniques are particularly useful for assessing alteration of fossil specimens (e.g., Gothmann et al., 2015), it is more challenging to evaluate diagenetic alteration of bulk carbonate sediments. Furthermore, these techniques do not provide a quantitative evaluation of the extend of alteration (fluid- vs. sediment-buffered) of individual proxies. Calcium isotope measurements in bulk carbonate sediments provide a powerful tool to evaluate the degree of diagenetic alteration in both shallow carbonate platforms (Fantle and Higgins, 2014, Higgins et al., 2018, Ahm et al., 2018) and deeper environments (Fantle and DePaolo, 2006, Fantle and DePaolo, 2007, Fantle et al., 2010) by quantifying the degree of diagenetic alteration and the amount of fluid that has interacted with the sediment during recrystallization. 
As a major constituent in carbonate sediments, $\mathrm{Ca}$ isotopes are inherently resistant to diagenetic

442 alteration. Carbonate $\delta^{44 / 40} \mathrm{Ca}$ values are only reset under conditions where there is sufficient supply of $\mathrm{Ca}^{2+}$ by fluid advection or diffusion to overwhelm $\mathrm{Ca}$ in the sediment (Higgins et al., 2018; Fantle and Higgins, 2014; Fantle and DePaolo, 2007; Fantle et al., 2010). Due to the relatively high concentrations of $\mathrm{Ca}$ in natural fluids (modern seawater $=10.28 \mathrm{mmol} / \mathrm{kg}$ ), sedimentary $\delta^{44 / 40} \mathrm{Ca}$ values are sensitive to alteration during early marine diagenesis (Higgins et al., 2018). For example, alteration of $\delta^{44 / 40} \mathrm{Ca}$ values has been observed in carbonate sediments in the Great Bahama Bank where subsurface circulation of seawater contributes to early neomorphism of primary aragonite to more stable carbonate phases such as low magnesium calcite or dolomite (Higgins et al., 2018). In these settings, primary aragonite with low $\delta^{44 / 40} \mathrm{Ca}$ values is deposited on the bank top and is subsequently recrystallized into secondary calcite and dolomite with higher $\delta^{44 / 40} \mathrm{Ca}$ values (Ahm et al., 2018; Higgins et al., 2018).

The behaviour of $\delta^{44 / 40} \mathrm{Ca}$ values during early marine diagenesis is a consequence of the rate dependence of $\mathrm{Ca}$ isotope fractionation in carbonate minerals (Blättler et al., 2015; Fantle and Higgins, 2014; Higgins et al., 2018; Tang et al., 2008b). The slow precipitation rates associated with recrystallization within the sediment pore-space do not appreciably fractionate $\mathrm{Ca}$ isotopes ( $\alpha \sim 1-0.9995$, Bradbury and Turchyn, 2018; DePaolo, 2011; Fantle and DePaolo, 2007; Jacobson and Holmden, 2008; Fantle, 2015). In contrast, the rates associated with precipitation of primary carbonate minerals in the surface ocean are orders of magnitude higher and can lead to significant $\mathrm{Ca}$ isotope fractionation (on average about $-1.5 \%$ for aragonite and $-0.9 \%$ o for calcite, Gussone et al., 2005; Marriott et al., 2004, see Figure 2 for the observed range of $\delta^{44 / 40} \mathrm{Ca}$ values). As a result, primary carbonate minerals, or carbonate sediments that have preserved their geochemical fingerprint during sediment-buffered diagenesis, tend to record generally lower $\delta^{44 / 40} \mathrm{Ca}$ values than carbonate sediments that have been significantly altered during early marine fluid-buffered diagenesis (e.g., dolomites and diagenetic cements, Fig. 2). 
Although early marine diagenesis is ubiquitous in carbonate sediments deposited in the marine

realm, other types of diagenesis may contribute to secondary alteration (e.g., late-stage diagenesis and meteoric diagenesis). The behaviour of $\delta^{44 / 40} \mathrm{Ca}$ values during different types and stages of diagenesis will depend on the specific composition of the diagenetic fluid and the primary sediment.

In studies of deep sea sediments, the lack of appreciable fractionation of $\mathrm{Ca}$ isotopes during near-equilibrium carbonate mineral dissolution and precipitation has led to the extensive use of pore-fluid $\mathrm{Ca}$ isotope measurements in studies of carbonate dissolution, precipitation, and recrystallization. In sediment-buffered systems with little fluid advection or diffusion, pore-fluid $\mathrm{Ca}^{2+}$ will approach the $\delta^{44 / 40} \mathrm{Ca}$ value of the carbonate sediment over a length scale that is proportional to the recrystallization rate (e.g., Bradbury and Turchyn, 2018; DePaolo, 2011; Fantle, 2015; Fantle and DePaolo, 2007; Fantle and DePaolo, 2006; Fantle, 2010; Turchyn and DePaolo, 2011). Slow recrystallization rates are recorded by pore-fluid $\delta^{44 / 40} \mathrm{Ca}$ profiles that are out of equilibrium from the surrounding carbonate sediment (e.g., Turchyn and DePaolo; 2011), whereas fast recrystallization rates are recorded by pore-fluid $\delta^{44 / 40} \mathrm{Ca}$ profiles that approach the isotopic composition of the sediment over short length-scales (shallow depths, e.g., Fantle, 2015; Fantle and DePaolo, 2007). In reactive-transport models, pore-fluid Ca isotope measurements are often combined with measurements of $\mathrm{Sr}$ concentrations and $\mathrm{Sr}$ isotopes to quantify carbonate recrystallization rates (Richter and DePaolo, 1987; 1988). In addition, by paring porefluid $\delta^{44 / 40} \mathrm{Ca}$ value with other geochemical proxies (e.g., Sr concentrations, $\delta \mathrm{D}, \delta^{18} \mathrm{O}$, and chloride concentrations), it is possible to identify different interstitial water masses such as glacial seawater stored deep within modern carbonate platforms (Blättler et al., 2019).

Calculations of recrystallization rates based on pore-fluid $\delta^{44 / 40} \mathrm{Ca}$ value can be complicated in systems that are affected by other processes than net carbonate recrystallization. For example, recrystallization rates may be underestimated in settings with high sedimentation rates where 
rapid burial effectively transports recently deposited pore-fluids to a greater relative depth in the sediment column, giving the appearance of larger length scales and slower recrystallization rates (Huber et al., 2017). The precipitation of authigenic carbonate minerals in organic-rich settings have also been observed to produce large changes in pore-fluid $\delta^{44 / 40} \mathrm{Ca}$ values (Blättler et al., 2015; Bradbury and Turchyn, 2018; Teichert et al., 2009, 2005). In these settings, it has been suggested that pore-fluid $\delta^{44 / 40} \mathrm{Ca}$ values should increase in response to a small Ca isotope fractionation during precipitation of authigenic carbonates (Teichert et al., 2009, 2005). In contrast, it has also been suggested that during organic matter remineralisation and $\mathrm{NH}_{4}^{+}$production, $\mathrm{Ca}$ is released due to ion exchange from clay minerals, contributing to a decrease in porefluid $\delta^{44 / 40}$ Ca values (Ockert et al., 2013; Teichert et al., 2009).

As $\mathrm{Ca}$ is a major cation in carbonate sediments, diagenetic processes that affect $\delta^{44 / 40} \mathrm{Ca}$ values will also affect other carbonate bound proxies. Early marine diagenesis in carbonate platform sediments from the Bahamas has been observed to produces distinct trends between $\delta^{44 / 40} \mathrm{Ca}$ values and $\mathrm{Sr} / \mathrm{Ca}$ ratios in limestone and $\delta^{44 / 40} \mathrm{Ca}$ and $\delta^{26} \mathrm{Mg}$ values in dolomites (Ahm et al., 2018; Higgins et al., 2018). Sediments that have recrystallized under fluid-buffered conditions show high $\delta^{44 / 40} \mathrm{Ca}$ values, low $\delta^{26} \mathrm{Mg}$ values, and low $\mathrm{Sr} / \mathrm{Ca}$ ratios (e.g., dolomites from the Bahamas, Fig. 2). In contrast, sediments that have recrystallized under sediment-buffered conditions are labelled by low $\delta^{44 / 40} \mathrm{Ca}$ values, high $\delta^{26} \mathrm{Mg}$ values and high $\mathrm{Sr} / \mathrm{Ca}$ ratios (Ahm et al., 2018; Higgins et al., 2018). By quantifying these geochemical signatures using diagenetic models, $\delta^{44 / 40} \mathrm{Ca}$ values can be used to identify fluid- from sediment-buffered endmembers and thereby constrain the degree of alteration of other carbonate-bound proxies (Ahm et al., 2019, 2018). In contrast to reactive-transport models that aim to constrain length-scales and recrystallization rates, the strengths of end-member models that compare multiple carbonate proxies in cross-plot space is that the degree of covariation is independent of advection and recrystallization rates (Ahm et al., 2018). 
Covariation between $\delta^{44 / 40} \mathrm{Ca}$ values and $\mathrm{Sr}$ concentrations has also been observed in fossil

517 specimens and marine cements from Cretaceous limestone (Steuber and Buhl, 2006). The lowest $\delta^{44 / 40} \mathrm{Ca}$ values and highest $\mathrm{Sr}$ concentrations were found in well preserved skeletal components, and the highest $\delta^{44 / 40} \mathrm{Ca}$ values and the lowest $\mathrm{Sr}$ concentrations were found in marine cements. Similar to the samples from the Bahamas, the variation of $\mathrm{Ca}$ isotope values and $\mathrm{Sr}$ concentrations observed in the Cretaceous limestones are interpreted to reflect the replacement of biological calcite by diagenetic marine calcite that records the composition of seawater at the time of alteration (Steuber and Buhl, 2006). Combined, these results suggest that early marine cements and dolomites that contain high $\delta^{44 / 40} \mathrm{Ca}$ values (fluid-buffered) may offer a yet to be explored archive of ancient seawater chemistry.

\section{Variation of oceanic $\mathrm{Ca}$ isotopes through time}

Changes in seawater $\mathrm{Ca}$ isotopes through time are of interest because flux imbalances may reflect changes in paleo-environmental conditions. Imbalances in the $\mathrm{Ca}$ isotope budget have been argued to reflect changes in the input fluxes - in other words, the weathering flux of dissolved Ca in rivers (de la Rocha and DePaolo, 2000; Fantle and DePaolo, 2005; Kasemann et al., 2005) — and relative changes in the output flux through $\mathrm{CaCO}_{3}$ burial (see section 2.1). Further, ocean acidification would dramatically decrease the $\mathrm{CaCO}_{3}$ burial flux, potentially leading to the dissolution of carbonate sediments, followed by enhanced continental weathering, higher seawater alkalinity, and increased carbonate precipitation (Payne et al., 2010). Because the Ca cycle is directly linked to the $\mathrm{C}$ cycle through $\mathrm{CaCO}_{3}$ precipitation and dissolution, seawater Ca isotope records have also been promoted as a proxy for constraining $\mathrm{C}$ cycle perturbations (Payne et al., 2010). 
There are several issues that can complicate the interpretation of seawater $\mathrm{Ca}$ isotopes as a record of $\mathrm{Ca}$ cycle imbalance. In order to significantly impact the seawater $\mathrm{Ca}$ isotope value, the perturbation must be of sufficient magnitude and duration, given the long residence time of $\mathrm{Ca}$ in the modern ocean (Section 2.1). Conversely, perturbations to the Ca isotope cycle that are significantly longer than the residence time will not result in equivalently long changes in the seawater $\mathrm{Ca}$ isotope composition, since the output flux on long time scales must be equivalent to the input flux (Blättler and Higgins, 2017). As a result, long-term shifts in Ca isotope values likely reflect changes in the fractionation of $\mathrm{Ca}$ isotopes of the output fluxes, not flux imbalances. Moreover, modelling of $\mathrm{Ca}$ and $\mathrm{C}$ cycles suggests that interpreting $\mathrm{Ca}$ isotope excursions that results from a transient $\mathrm{C}$ cycle perturbation requires coupling $\mathrm{Ca}$ and $\mathrm{C}$ through the carbonate system to correctly interpret these records (Komar and Zeebe, 2016).

Tracking the evolution of seawater isotopes through time is also complicated by the variable isotope fractionation that occurs during the precipitation of Ca-bearing minerals (summarized in Section 2.3). Challenges with variable fractionation have been identified for bulk carbonate records across the geologic record (Ahm et al., 2019; Farkaš et al., 2016; Husson et al., 2015; Jost et al., 2014; Lau et al., 2017), with aragonite vs. high-magnesium calcite, and diagenesis, identified as important drivers of the bulk carbonate $\mathrm{Ca}$ isotope signature (summarized in Section 2.3). Moreover, the bulk carbonate sediment fractionation can be spatially variable depending on the mixture of different carbonate components inherent to a depositional environment (e.g., Silva-Tamayo et al., 2018; Wang et al., 2019). One approach to reduce the uncertainty associated with $\mathrm{Ca}$ isotope fractionation into bulk $\mathrm{CaCO}_{3}$ rocks is to utilize other archives. For example, the skeletal remains of brachiopods, belemnites, and foraminifera have a known mineralogy and are often more resistant to post-depositional alteration (Veizer et al., 1999), and have been a focus for many records (Blättler et al., 2012; Farkaš et al., 2007a, 2007b; Heuser et al., 2005; Sime et al., 2007). Other common Ca-bearing authigenic marine minerals, such as barite (Griffith et al., 2008a), evaporites (Blättler et al., 2017; Blättler et al., 2018) and 
phosphates (Schmitt et al., 2003; Soudry et al., 2006; Arning et al., 2009), have also been used to reconstruct seawater $\mathrm{Ca}$ isotope signatures.

In this section, we will describe records of Ca isotopes through Earth history and their implications for interpretations for these data. In particular, we will highlight the complexities of $\mathrm{Ca}$ isotope incorporation into $\mathrm{CaCO}_{3}$, and the implications for interpreting $\mathrm{Ca}$ and other biogeochemical cycles.

\subsection{Transitional periods in Earth history and short time events}

\subsubsection{Carbon cycle perturbations and mass extinction events}

Due to the link between the $\mathrm{Ca}$ and $\mathrm{C}$ cycles, $\mathrm{Ca}$ isotope records have been applied to major carbon cycle perturbations with the intent to test the degree of environmental impact. Examples of past climate changes have been a particular focus because periods of transiently higher atmospheric $p \mathrm{CO}_{2}$ are expected to exhibit a cascade of environmental effects, such as increased continental weathering, ocean acidification, and oceanic anoxia-all related to carbon cycle feedbacks that counteract changes in $p \mathrm{CO}_{2}$ (Archer, 2005; Berner, 2004). As weathering, acidification, and anoxia would individually impact the Ca cycle through direct changes in the riverine $\mathrm{Ca}$ flux, ocean $\mathrm{pH}$, and alkalinity, $\mathrm{Ca}$ isotopes are thought to be an ideal proxy for the $\mathrm{Ca}$ and carbonate systems (Fig. 6). Many of these periods also correspond to major extinctions, with the trigger for extinctions often attributed to the environmental changes that are listed above.

For example, the end-Permian mass extinction (ca. 251.9 Ma), which saw the loss of over $80 \%$ of marine genera, is generally linked to the emplacement of the Siberian Traps, a large igneous province that released an estimated $30,000 \times 10^{15} \mathrm{~g}$ of carbon as a result of volcanic degassing and volatilization of the coal- and limestone-rich strata (reviewed in Burgess et al., 2014; Payne 
and Clapham, 2012). The boundary is coincident with a large negative carbon isotope excursion, likely related to the release of mantle-derived and other ${ }^{13} \mathrm{C}$-depleted sources (e.g., Cui et al., 2015). Payne et al. (2010) observed a negative $\delta^{44 / 40}$ Ca excursion of $\sim 0.3 \%$ in shallow marine platform carbonates in the Dajiang section, south China that they attributed to a combination of increased continental weathering and acidification, which reduced the carbonate precipitation and burial flux. A Ca isotope excursion of similar magnitude, coinciding with the $\delta^{13} \mathrm{C}$ shift, was also recorded in conodont fossils composed of apatite from Meishan in south China (Hinojosa et al., 2012), though this negative excursion is absent in Meishan carbonates (Wang et al., 2019). Furthermore, a boundary negative shift in $\delta^{44 / 40} \mathrm{Ca}$ has also been observed in carbonate successions from Italy, Turkey, and Oman, although the size of the shift and their absolute values differ among sites (Silva-Tamayo et al., 2018). Different mixtures of calcite and aragonite at each site is hypothesized to cause this variability among the $\delta^{44 / 40} \mathrm{Ca}$ datasets, but it was noted that the overall reproducibility of a negative $\delta^{44 / 40} \mathrm{Ca}$ shift in multiple sections and replicated in conodont apatite supported a secular change in Ca cycling in these environments, rather than a diagenetic fingerprint (Silva-Tamayo et al., 2018).

Several other studies have added insight into Permian-Triassic Ca isotope records. First, Komar and Zeebe (2016) noted that coupling $\mathrm{Ca}$ and $\mathrm{C}$ cycles in numerical box models is a critical step in elucidating the drivers of Ca cycle behaviour. Because changes in Ca cycling via weathering or $\mathrm{CaCO}_{3}$ precipitation are directly linked with ocean carbonate chemistry, the predicted negative excursion that results from acidification is relatively small $(<0.1 \%)$. These authors instead propose that volcanism, a reduction in biological carbon export, and $\mathrm{Ca}$ isotope fractionation that varies depending on the seawater $\left[\mathrm{CO}_{3}{ }^{2-}\right]$ are the cause for the negative shift, although the relationship between fractionation and $\left[\mathrm{CO}_{3}{ }^{2-}\right]$ is controversial (AlKhatib and Eisenhauer, 2017a; Lemarchand et al., 2004; Tang et al., 2008b). Alternatively, the negative $\delta^{44 / 40} \mathrm{Ca}$ shift at the extinction boundary at Dajiang parallels a negative shift in $\delta^{88 / 86} \mathrm{Sr}$ whereas ${ }^{87} \mathrm{Sr} /{ }^{86} \mathrm{Sr}$ is 
invariant, leading to the hypothesis that a seawater shift in $\delta^{44 / 40} \mathrm{Ca}$ was caused by a major regression that exposed and weathered shallow shelfal carbonates (Wang et al., 2019).

A study of Lower-to-Middle Triassic $\delta^{44 / 40} \mathrm{Ca}$ from platform carbonates in south China and Turkey identified an additional challenge. Lau et al. (2017) observed that $\delta^{44 / 40} \mathrm{Ca}$ data from the two sections do not exhibit similar absolute values nor patterns through this time interval, which is hypothesized to reflect different $\mathrm{CaCO}_{3}$ mineralogies as well as variable recrystallization (fluid- and sediment-buffered). These syndepositional and early diagenetic changes may be accounted for via additional geochemical observations, such as comparison with Sr concentrations. Inconsistent $\delta^{44 / 40} \mathrm{Ca}$ datasets in multiple carbonate sections across the Middle-to-Late Permian boundary illustrate the ability of local effects, whether $\mathrm{CaCO}_{3}$ mineralogy, diagenesis, or other conditions, to impact the geological $\delta^{44 / 40} \mathrm{Ca}$ value (Jost et al., 2014).

Similar to the Permian-Triassic boundary, the interplay between changes in seawater chemistry, $\mathrm{CaCO}_{3}$ mineralogy, and diagenesis was observed for the end-Triassic extinction and attributed to volcanism and carbon release associated with the Central Atlantic Magmatic Province (CAMP). A negative $\delta^{44 / 40} \mathrm{Ca}$ excursion of $\sim 0.8 \%$ was observed in shallow marine carbonate rocks from Italy (Jost et al., 2017). Because this excursion is much larger than can be explained only by an imbalance in the $\mathrm{Ca}$ and $\mathrm{C}$ cycles, these authors attribute this shift to a combination of acidification (seawater variability) and changes in $\mathrm{CaCO}_{3}$ mineralogy (Ca isotope fractionation).

Transient Cenozoic volcanic events have also been investigated with $\delta^{44 / 40} \mathrm{Ca}$ data. In the Cenozoic, negative $\delta^{13} \mathrm{C}$ excursions - also known as hyperthermals - are much shorter than in preceding time intervals (on the order of $10^{4}$ to $10^{5} \mathrm{yr}$ ). A study of $\delta^{44 / 40} \mathrm{Ca}$ values in marine barite and bulk carbonate across the Eocene-Oligocene Transition (EOT, ca. $34 \mathrm{Ma}$ ) observed a negative shift of $\sim 0.4 \%$ in the bulk carbonate, but no change in the barite record (Griffith et al., 2011). This multi-mineral approach suggests that there was no change in seawater $\delta^{44 / 40} \mathrm{Ca}$, and 
that bulk carbonate $\delta^{44 / 40} \mathrm{Ca}$ values are reflecting other effects from variable isotopic fractionation of different biogenic and diagenetic phases. During the most significant Cenozoic hyperthermal, the Paleocene-Eocene Thermal Maximum (PETM, ca. $55 \mathrm{Ma}$ ), $\delta^{44 / 40} \mathrm{Ca}$ in marine barite and bulk carbonate were also compared (Griffith et al., 2015). Similar to the EOT, the carbonate and barite records do not show agreement—with the bulk carbonate $\delta^{44 / 40} \mathrm{Ca}$ data interpreted as a diagenetic fingerprint of acidification within the sedimentary column. This study proposed a new mechanism-sediment dissolution-for generating apparent stratigraphic shifts in bulk carbonate $\delta^{44 / 40} \mathrm{Ca}$. As an alternative hypothesis, Fantle and Ridgwell suggested that the observed $\mathrm{Ca}$ isotope signal of the carbonate may result from an increase in $\delta^{44 / 40} \mathrm{Ca}$ bulk carbonate caused by the formation of authigenic carbonates due to a saturation overshoot in response to ocean acidification events (in rev., this issue).

Together, these studies highlight the evolution of $\delta^{44 / 40} \mathrm{Ca}$ data in the Phanerozoic, and the increasing recognition that while seawater $\mathrm{Ca}$ was likely to have been impacted during these events, the resulting impact on $\delta^{44 / 40} \mathrm{Ca}$ was small and may have been dwarfed by local processes, including $\mathrm{CaCO}_{3}$ mineralogy, secondary diagenesis, sediment dissolution, and a host of other factors. Some of these processes may have been global (e.g., PETM), resulting in potentially reproducible signals that are not a reflection of seawater $\mathrm{Ca}$ and $\mathrm{C}$ cycle change. Additionally, the reproducibility of the end-Permian $\delta^{44 / 40} \mathrm{Ca}$ negative shift—despite some variability-suggests that there likely is a global signal that can be extracted from these types of carbon cycle perturbations. Importantly, apparent global shifts in $\delta^{44 / 40} \mathrm{Ca}$ can still be attributed to local process on carbonate platforms (i.e. mineralogy and early diagenesis) that record wide-spread changes in the cycling of $\mathrm{Ca}$ and $\mathrm{C}$ in shallow restricted environments related to changes in sea level, climate and oxygenation. 
Perturbations in the global Ca-C-cycle also take place during Mesozoic Oceanic Anoxic Events (OAE). Similar to mass extinction events, Ca isotope observations differ considerably between individual OAEs. For the Pliensbachian-Toarcian transition and the Toarcian anoxic event (183Ma), negative $\delta^{44 / 40} \mathrm{Ca}$ excursions of up to $0.5 \%$ were reported (Brazier et al. 2015). Similarly, negative excursions were shown by Blättler et al. (2011) for Cretaceous OAE 1a $(\sim 123 \mathrm{Ma})$ and $2(\sim 93.9 \mathrm{Ma})$. Both studies argue that the Ca isotope fractionation remained more or less constant during the OAE and bulk carbonate $\delta^{44 / 40} \mathrm{Ca}$ patterns reflect changes in seawater isotope composition caused by an increased weathering flux. In contrast, Du Vivier et al. (2015) reported positive $\delta^{44 / 40} \mathrm{Ca}$ excursions for OAE2 in the order of 0.1 to $0.2 \%$, obtained from highprecision TIMS analyses $(2 \sigma \sim 0.04)$ from the Eastbourne chalk samples, which was not captured by the previously measured, less precise data based on multi-collector ICP-MS from the same section (Blättler et al., 2011). Du Vivier et al. (2015) attribute their positive Ca excursion to a decrease in the magnitude of the $\mathrm{Ca}$ isotope fractionation factor of the archive-material related to an increase in $\mathrm{Ca}: \mathrm{CO}_{3}$ ratios of seawater during transient ocean acidification.

It should be noted that other studies have suggested that a reduction in $\mathrm{Ca}$ isotope fractionation during phases of ocean acidification may not exclusively be related to an inferred increase in the $\mathrm{Ca}: \mathrm{CO}_{3}$ ratio. For instance, recently it has been suggested that the formation of authigenic carbonates can be a mechanism that significantly impact bulk sediment $\delta^{44 / 40} \mathrm{Ca}$ (Fantle and Ridgwell, in rev./this issue). In addition, as biominerals show taxon-specific fractionation characteristics often different from non-skeletal carbonate minerals, sediment composition can also play an important role (faunal composition, ratio of skeletal to non-skeletal; Fig. 2). In particular, culture experiments show that reduced seawater $\mathrm{Ca}$ and $\mathrm{CO}_{3}{ }^{2-}$ concentrations are associated with reduced $\mathrm{Ca}$ isotope fractionation in coccolithophores (Gussone et al., 2007, Meija et al. 2018) and increasing $\mathrm{Ca}$ isotope fractionation is observed with increasing seawater $\mathrm{Ca}: \mathrm{CO}_{3}$ ratios in foraminifera (Roberts et al., 2018). Although culture experiments are difficult to extend to natural settings, it is likely that sediments containing different contributions of skeletal and 
non-skeletal carbonates may show considerably different $\mathrm{Ca}$ isotope profiles, highlighting the importance of detailed sample characterization.

\subsubsection{Glaciations in the Neoproterozoic and Paleozoic}

As there are no established biostratigraphic frameworks and a general paucity of absolute ages, in the Neoproterozoic ( 1000-541 Ma) carbon isotope stratigraphy has been widely used to create age models (e.g., Cox et al., 2016; Halverson et al., 2005; Hoffman and Schrag, 2002). The Neoproterozoic carbonate carbon isotope record is characterized by generally high background values of $\sim 5-10 \%$ interrupted by dramatic negative excursions with values down to 15\%. Intriguingly, most of these negative excursions have been linked to the onset and aftermath of globally expansive glaciations. However, it is still widely debated whether these enigmatic negative excursions record changes in the global carbon cycle (e.g., Bjerrum and Canfield, 2011; Rothman et al., 2003; Tziperman et al., 2011), synchronous shifts in local conditions on ancient platforms (Ahm et al., 2019; Swart 2008), or diagenetic events (Derry, 2010; Knauth and Kennedy, 2009). Combining carbon isotope records with measurements of $\delta^{44 / 40} \mathrm{Ca}$ values offers a tool to assess the origin of the Neoproterozoic carbon isotope excursions.

The first published Neoproterozoic Ca isotope record is from carbonate rocks bracketing the last Snowball Earth event - the Marinoan glaciation (Kasemann et al., 2005). By combining $\delta^{44 / 40} \mathrm{Ca}$ values with both boron and magnesium isotope measurements from the Ombaatjie and Maieberg formations in Namibia, Kasemann et al. $(2014,2005)$ aimed to estimate the perturbation in atmospheric $p \mathrm{CO} 2$ levels, seawater $\mathrm{pH}$, and alkalinity inputs associated with a Snowball Earth event. In the glacial aftermath, these authors found a $\sim 0.7 \%$ negative $\mathrm{Ca}$ isotope excursion in the basal Ediacaran cap carbonates. A large post-glacial negative Ca isotope excursion has also been found in Brazil, NW Canada, and China (Silva-Tamayo et al., 2010, Sawaki et al., 2014). Similarly, the observations from the younger Marinoan glaciation have 
been reproduced for the older Snowball Event - the Sturtian glaciation - that also show a negative $\mathrm{Ca}$ isotope excursion during the glacial aftermath (Silva-Tamaya et al., 2010). These pioneering studies attributed the large changes in $\delta^{44 / 40} \mathrm{Ca}$ values to transient changes in the postglacial marine $\mathrm{Ca}$ cycle, with the negative excursion caused by $\mathrm{Ca}^{2+}$ weathering inputs exceeding $\mathrm{Ca}^{2+}$ removal through carbonate precipitation.

New observations that document the behaviour of bulk sediment $\delta^{44 / 40} \mathrm{Ca}$ values in modern carbonate platforms (Higgins et al., 2018) have inspired a reevaluation of the Neoproterozoic Ca isotope records (Ahm et al., 2019; Husson et al., 2015; Wei et al., 2019). These studies have demonstrated that the effects of carbonate mineralogy (aragonite, calcite, and dolomite) and diagenesis (fluid- and sediment-buffered) can produce large stratigraphic changes in $\delta^{44 / 40} \mathrm{Ca}$ values that are independent of changes in the global $\mathrm{Ca}$ and carbon cycles. In addition, modelling studies have demonstrated that the combined changes in weathering rates and ocean acidification are incapable of producing change in seawater $\delta^{44 / 40} \mathrm{Ca}$ values of more than $\sim 0.3 \%$ o (Komar and Zeebe, 2016) thereby raising questions about the original interpretations of Neoproterozoic $\mathrm{Ca}$ isotope variability.

More recently, new research has attributed the large changes in $\delta^{44 / 40} \mathrm{Ca}$ values in the Neoproterozoic to changes in carbonate mineralogy and diagenesis. For example, $\delta^{44 / 40} \mathrm{Ca}$ values in the post-glacial basal Ediacaran cap carbonates are spatially variable recording a range from $\sim-0.2 \%$ to $1.4 \%$ both regionally and globally (Ahm et al., 2019). This geochemical variability can be explained by early diagenetic dolomitisation of aragonite along a spectrum of fluid to sediment-buffered diagenetic conditions (Ahm et al., 2019). Driven by the post-glacial sea-level rise, aragonite sediments from the outer platform environments were dolomitized under fluidbuffered conditions (in reaction with seawater), whereas aragonite sediments on the inner platform were dolomitized under more sediment-buffered conditions and in reaction with glacial meltwater (Ahm et al., 2019) or mixtures between seawater and meltwater (Wei et al., 2019). 
Furthermore, a numerical diagenetic model combining $\delta^{44 / 40} \mathrm{Ca}$ values, $\mathrm{Sr} / \mathrm{Ca}$ ratios, magnesium

741

742 isotopes and carbon isotopes (Ahm et al., 2018, 2019) showed that it is possible to extract the chemical composition of the dolomitizing fluid (glacial seawater) and the primary mineral (platform aragonite). This study highlights the application of Ca isotopes for constraining geochemical signals of a wide range of elements in ancient bulk carbonate sediments.

Glacial intervals associated with changes in both $\mathrm{Ca}$ and carbon isotopes have also been documented in the Early Paleozoic. In the Monitor Range in Central Nevada, the end-Ordovician Hirnantian glaciation is marked by a positive carbon isotope excursion of up to $\sim 7 \%$ and a large negative $\mathrm{Ca}$ isotope excursion of $\sim 0.5 \%$ (Holmden et al., 2012). This apparent synchronicity of $\mathrm{Ca}$ and $\mathrm{C}$ isotope excursions is inconsistent with what is known about global $\mathrm{Ca}$ and $\mathrm{C}$ geochemical cycles in the modern ocean because the residence time of $\mathrm{Ca}$ is longer than that of $\mathrm{C}$ (Holmden et al., 2012). Instead, these authors attributed the changes in Ca isotopes across the Hirnantian glaciation to restriction between ocean and epeiric seas with increased isotopically light Ca-inputs by submarine ground water discharge. Kimmig and Holmden (2017) combined $\delta^{44 / 40} \mathrm{Ca}$ values with magnesium isotope measurements across the Hirnantian glacial interval and showed that the negative $\mathrm{Ca}$ isotope values and positive magnesium isotope values can be attributed to changes in aragonite abundance. Although the Ordovician ocean generally is classified as a 'calcite sea', the precipitation of primary aragonite in carbonate platform environments has also been identified by low $\delta^{44 / 40} \mathrm{Ca}$ values and high $\mathrm{Sr} / \mathrm{Ca}$ ratios in sections from Anticosti island, correlating with the Hirnantian glacio-eustatic sealevel fall (Jones et al., in press).

Similar to the end-Ordovician interval, the Late Silurian is associated with major climatic changes, abrupt cooling, and global sea-level fluctuations. However, while Late Silurian marine carbonates record a large positive carbon isotope excursion $(\sim 8.5 \%)$, there is no parallel excursion in Ca isotopes. Bulk sediment $\delta^{44 / 40} \mathrm{Ca}$ values are constantly low $(\sim 0.3 \%$ o $)$ during the initial 
stages of the carbon isotope excursion and subsequently increase to $\sim 1 \%$ in parallel with the decrease in carbon isotope values back towards 0\%o (Farkaš et al., 2016). These authors identified a linear relationship between $\mathrm{Sr}$ concentrations and $\delta^{44 / 40} \mathrm{Ca}$ values, suggesting that changes in precipitation rates, carbonate mineralogy (aragonite to calcite), and/or diagenesis (fluid- to sediment-buffered) may have been related to the changes in Ca isotope values and the decoupling from the carbon isotope record (Fig. 3).

The observed relationship between glacial intervals and stratigraphic changes in $\mathrm{Ca}$ isotope ratios in the Neoproterozoic and Early Paleozoic points to a link between climate, sea-level changes, carbonate mineralogy, and diagenesis. Changes in sea level associated with glaciation are capable of producing globally synchronous changes in local platform environments by increasing restriction, changing local surface water chemistry, and changing rates of subsurface fluid flow and carbonate diagenesis (e.g., size of freshwater lens, groundwater discharge, and buoyancy driven seawater recirculation). Importantly, the pre-Mesozoic bulk carbonate record is composed of sediments derived from carbonate platforms that are not always reliable archives of open ocean conditions (Higgins et al., 2018; Swart, 2008; Swart and Eberli, 2005). With these new insights, $\mathrm{Ca}$ isotopes provide an important tool to disentangling the local processes that operate on and within carbonate platforms from global changes in seawater chemistry.

\subsection{Long-term trends}

Long-term records of $\delta^{44 / 40} \mathrm{Ca}$ have been generated from a number of sedimentary archives. However, a comparison between different Neogene records demonstrates large differences depending on the analysed sample material (Fig. 4). Overall, records based on bulk carbonate sediments (De la Rocha and DePaolo, 2000; Fantle and DePaolo, 2005) display larger variability compared to barite (Griffith et al., 2008a), phosphate (Schmitt et al., 2003) and foraminiferal records (Heuser et al., 2005; Sime et al., 2007). The differences among individual archives are 
likely a result of both diagenesis and species-specific variability in the Ca isotope fractionation factor (Fig. 4).

A Late Mesozoic dataset of $\delta^{44 / 40} \mathrm{Ca}$ in skeletal carbonates, belemnites, and brachiopods was interpreted to reflect changes in global seawater $\delta^{44 / 40} \mathrm{Ca}$ values through time driven by changing input fluxes of Ca (Farkaš et al., 2007b). Subsequently, a Phanerozoic compilation of $\delta^{44 / 40} \mathrm{Ca}$ in skeletal carbonates (brachiopods, belemnites, and planktonic foraminifera) captured a positive shift of $\sim 0.7 \%$ from the Ordovician until today, with short-term oscillations superimposed over this first-order trend (Farkaš et al., 2007a). However, box modelling results do not support variations in $\mathrm{Ca}$ mass balance to explain the overall trend. Instead, changing $\mathrm{Ca}$ isotope fractionation of carbonate sediments, related to oscillating calcite-aragonite seas (e.g., Stanley, 2006), was proposed as a primary driver of seawater $\delta^{44 / 40} \mathrm{Ca}$ through time. This firstorder positive shift between the Early Silurian and Late Devonian/Early Carboniferous has also been confirmed by conodont $\delta^{44 / 40} \mathrm{Ca}$ data (Le Houedec et al., 2017). Blätter et al. (2012) also advocated the hypothesis that the mode of carbonate precipitation may be responsible for firstorder trends in $\delta^{44 / 40} \mathrm{Ca}$, and further proposed that variability in seawater $\delta^{44 / 40} \mathrm{Ca}$ due to $\mathrm{CaCO}_{3}$ mineralogy became dampened after the advent of pelagic calcification in the Mesozoic. The carbonate $\delta^{44 / 40} \mathrm{Ca}$ record was recently extended to the Archean (ca. $3 \mathrm{Ga}$; Blätter and Higgins, 2017), with values that predominantly record values similar to Bulk Silicate Earth (BSE). This observation reflects the fact that skeletal $\mathrm{CaCO}_{3}$ does not appear in the fossil record until the Ediacaran, and that partitioning of $\delta^{44 / 40} \mathrm{Ca}$ in pelagic vs. shallow carbonate sinks was not apparent in the Precambrian.

In addition to linking $\delta^{44 / 40} \mathrm{Ca}$ values with the evolution of the carbonate system through time, there is a close relationship between $\delta^{44 / 40} \mathrm{Ca}$ and seawater sulphate concentrations. In a study of Phanerozoic $\delta^{44 / 40} \mathrm{Ca}$, Farkaš et al. (2007a) proposed that short-term variability might have been related to the ratios of $\mathrm{Ca}$ to bicarbonate and sulphate in rivers, as well as dolomite 
precipitation. Subsequent studies of $\delta^{44 / 40} \mathrm{Ca}$ in anhydrite $\left(\mathrm{CaSO}_{4}\right)$ and gypsum $\left(\mathrm{CaSO}_{4} \cdot 2 \mathrm{H}_{2} \mathrm{O}\right)$ evaporites have been used to reconstruct the relative concentration of $\mathrm{Ca}$ and sulphate in the past — a key clue into the evolution of the seawater sulphate pool, and thus, ocean oxygenation. Briefly, this method is based on the Ca isotope fractionation between evaporites and seawater, leading to Rayleigh-type distillation of the fluid under conditions where available $\mathrm{Ca}^{2+}<$ sulphate (Blättler and Higgins, 2014). In contrast, in conditions where sulphate limits Ca sulphate precipitation, there will be little consumption of the $\mathrm{Ca}$ in the fluid and $\delta^{44 / 40} \mathrm{Ca}$ values will remain lower. This method has been used to identify periods of sulphate-rich and Ca-rich oceans in the Phanerozoic (Blätter and Higgins, 2014), in the Neoproterozoic (Blättler et al., 2020), and has also extended to a 2 Ga sedimentary evaporite sequence to constrain the concentration of marine sulphate to $>10 \mathrm{mmol} / \mathrm{kg}$ as additional evidence of significant ocean oxygenation following the Great Oxidation Event (Blätter et al., 2018). As another creative approach, the $\delta^{44 / 40} \mathrm{Ca}$ in 2.7 to $1.9 \mathrm{Ga}$ evaporitic sedimentary carbonates exhibited very limited variability (Blätter et al., 2017). Based on experimental calibrations, the Ca-to-alkalinity ratio was reconstructed with evidence for oceans that were less alkaline than previously proposed, providing new constraints on ocean $\mathrm{pH}$ and atmospheric $p \mathrm{CO}_{2}$ in the Archean and Paleoproterozoic that can be used to test hypotheses for the so called Faint Young Sun Paradox.

\section{Outlook and future directions}

As discussed in the previous sections, the application and interpretation of Ca isotopes for deeptime records have evolved tremendously since early papers published in the late 1990s and early 2000s. Here, we summarize our view on the revised approaches for using Ca isotopes. First, we discuss the importance of identifying and selecting biogenic (skeletal) materials for reconstructing seawater $\delta^{44 / 40} \mathrm{Ca}$ through time. Second, we propose that new discoveries about bulk carbonate $\delta^{44 / 40} \mathrm{Ca}$ may be useful for elucidating the variability in depositional conditions, 
including carbonate mineralogy and fluid interactions, in particular in combination with other proxies such as $\mathrm{Sr}$ concentrations and $\mathrm{Mg}$ isotopes. As Ca isotope systematics continue to be refined, it can be anticipated that these new approaches will lead to reinterpretation and assessments of deep-time records.

\subsection{Selection of archives}

The selection of appropriate archives is of particular importance for the $\delta^{44 / 40} \mathrm{Ca}_{\text {sw }}$ reconstruction and a critical determination of the best available archive may be required for different time intervals and sedimentary facies. For relatively young records, suitable archives can be identified using calibrations based on culture experiments and samples collected from the environment, while for older eras, modern analogues are not readily available.

Archives selected from the depositional record need to balance the requirements in terms of fractionation characteristics, availability (abundance, continuity throughout the record and ability to isolate), and preservation. Possible limitations of archives with suitable fractionation patterns include aragonite corals, which are susceptible to recrystallisation, and coccolithophores, which are difficult to isolate, because of their small size. The further back in time, the more pronounced the uncertainties become and simultaneously, the potential options for archives become more limited.

The use of biomineral archives is complicated when measuring extinct species where the fractionation characteristics need to be approximated using cross calibration with modern taxa, as no direct calibrations are possible. If the dominant fractionation mechanisms remained invariable throughout Earth history, this approach may result in consistent $\delta^{44 / 40} \mathrm{Ca}_{\text {sw }}$ records. However, identifying suitable archives becomes more complicated considering potential shifts in fractionation characteristics over very long time periods, such as due to changing ocean 
chemistry and/or adaptation of biomineralisation strategies. Although the effect of environmental parameters on $\mathrm{Ca}$ isotope fractionation can be tested in laboratory experiments, short-term experiments may not capture the effect of major environmental changes over long time periods, as taxa may behave differently, generating stress-induced proxy signals when exposed to environmental stress in lab experiments. Moreover, evolutionary adaption may occur on longer time scales during slow natural changes, leading to a different response to environmental changes. In addition, the composition of ocean water is not fully constrained in terms of temperature and chemical composition (e.g., dissolved inorganic carbon (DIC), stoichiometry (Ca:SO $\mathrm{SO}_{4} \mathrm{Ca}: \mathrm{CO}_{3}$, $\Omega, \mathrm{Ca}^{2+}$, etc.), which adds further uncertainties for estimating $\Delta_{\text {sed }}$ and $\Delta^{44 / 40} \mathrm{Ca}$ of the studied archives.

Depending on the availability of archives, different strategies have been applied to obtain $\delta^{44 / 40} \mathrm{Ca}_{\mathrm{sw}}$ records, such as monospecific records or records with a limited number of different related taxa. Compared to bulk carbonate $\delta^{44 / 40} \mathrm{Ca}$ records, artefacts caused by faunal/floral shifts and species-specific fractionation can be largely reduced (e.g., Heuser et al., 2005; Sime et al., 2007). To further minimize potential artefacts in the paleo- $\delta^{44 / 40} \mathrm{Ca}_{\mathrm{sw}}$ record caused by differential fractionation patterns of taxa, the application of parallel records of different taxa/archives was applied (e.g., Brazier et al., 2015; Gussone and Friedrich, 2018). Another strategy is to avoid carbonate archives and instead use passive tracers, such as barite (e.g., Griffith et al., 2008a) and phosphates (e.g., Arning et al., 2009; Schmitt et al., 2003; Soudry et al., 2006). In this context, the combination of passive and bulk tracers (Fantle, 2010; Hinojosa et al., 2012; Fantle and Tipper, 2014) is of special interest, as this approach may be used to identify changes in the fractionation factor $\left(\Delta_{\mathrm{sed}}\right)$. As the dominant $\mathrm{Ca}$ sink, a potential complication of using biogenic carbonates could be if a long-term shift in $\delta^{44 / 40} \mathrm{Ca}_{\mathrm{sw}}$ was caused by a shift in $\alpha_{\text {bio-carb }}$ (the $\mathrm{Ca}$ isotope fractionation of biogenic carbonates relative to seawater), which would then not be apparent in the recorded $\delta^{44 / 40} \mathrm{Ca}$ carbonate. In contrast, a change in the fractionation factor of a passive tracer would be reflected by a change of $\delta^{44 / 40} \mathrm{Ca}$ recorded in the archive, even 
though $\delta^{44 / 40} \mathrm{Ca}_{\mathrm{sw}}$ may have remained more or less constant. However, not all $\mathrm{CaCO}_{3}$-forming taxa fractionate in the same way as the bulk $\mathrm{CaCO}_{3}$ output, due to the taxon-specific $\mathrm{Ca}$ isotope fractionation. Consequently, depending on their abundance and contribution to the $\mathrm{CaCO}_{3}$ export production, some $\mathrm{CaCO}_{3}$-forming taxa may act as either passive or bulk tracers. A recently suggested concept to determine past $\delta^{44 / 40} \mathrm{Ca}_{\mathrm{sw}}$ is the intercept method, which utilizes the different slopes of taxa in the $\delta^{44 / 40} \mathrm{Ca}-\mathrm{Sr} / \mathrm{Ca}$ space. Assuming that the positions of the fractionation arrays stay constant and individuals only shift their position on the respective slopes due to environmental or physiological control, the $\mathrm{Sr} / \mathrm{Ca}$ and $\delta^{44 / 40} \mathrm{Ca}$ of past seawater can be estimated from the intercept of two fractionation arrays of species/cements featuring different $\delta^{44 / 40} \mathrm{Ca}$ $\mathrm{Sr} / \mathrm{Ca}$ partitioning characteristics. (Figure 5B, Gussone and Greifelt, 2019). This approach is complementary to an earlier approach using the offset between diagenetically overprinted calcite and the modern fractionation array of inorganic calcite and accordingly the $\mathrm{Y}$-axis intercept of the regression trough the ancient calcites (Figure 5 A, Tang et al. 2008b; Farkaš et al. 2016).

For much of Earth's history, as the availability of easily calibrated archives becomes scarcer, it becomes increasingly important to assess and discuss the limitations and uncertainties related to the use of the selected biogenic archive. Even deeper in time, prior to the advent of skeletal biomineralisation, or during major environmental perturbations that resulted in discontinuous skeletal records, using only biominerals becomes impossible or challenging. As a result, bulk carbonate sediments may become more important options.

\subsection{Bulk carbonate sediments}

As highlighted previously, combining bulk carbonate $\mathrm{Ca}$ isotopes with other carbonate-bound proxies, such as carbon isotopes, can provide unique constraints on the carbon cycle. For example, if seawater $\delta^{44 / 40} \mathrm{Ca}$ can be captured from the bulk carbonate record, estimates of the $\mathrm{CO}_{2}$ fluxes that lead to coupled perturbations to $\mathrm{C}$ and $\mathrm{Ca}$ cycles can be inferred (e.g., Komar 
and Zeebe, 2016; Payne et al., 2010). However, it has been shown that large changes in bulk $\mathrm{Ca}$ isotope records cannot be driven purely by changes in global fluxes $(<0.15 \%)$ or ocean acidification (carbonate ion effect $<0.15 \%$ ), which combined can only account for a maximum perturbation of $\sim 0.2-0.3 \%$ o (Komar and Zeebe, 2016). Calcium isotope perturbations that are larger than feasible are indicative of local depositional conditions that impacted $\mathrm{Ca}$ isotope fractionation or subsequent diagenetic recrystallization and resetting. These local and diagenetic effects can also modulate the associated carbon isotope records but by combining $\mathrm{C}$ and Ca isotope models it may be possible to isolate the potential effects of acidification and mineralogy (Jost et al., 2017). Changes in local depositional conditions can possibly occur on a global scale if they are related to a widely expressed perturbation such as acidification or sea-level related diagenesis (Ahm et al., 2019; Griffith et al., 2015). Moreover, local factors can act to amplify or depress concurrent seawater $\delta^{44 / 40} \mathrm{Ca}$ perturbations.

For example, the systematic covariation between $\delta^{44 / 40} \mathrm{Ca}$ values and $\mathrm{Sr} / \mathrm{Ca}$ ratios in diagenetic limestones, and $\delta^{44 / 40} \mathrm{Ca}$ and $\delta^{26} \mathrm{Mg}$ values in dolomites, can provide additional insights into the origins and preservation of $\delta^{13} \mathrm{C}$ values in carbonates rocks. As the ratio of $\mathrm{Ca}$ and carbon are broadly similarly abundant in seawater and carbonates, their behaviour during fluid- and sediment-buffered early marine diagenesis is expected to be similar (Ahm et al., 2018). Interpreted through the lens of diagenesis, stratigraphic excursions in $\delta^{13} \mathrm{C}$ values that correlate with stratigraphic excursions in $\delta^{44 / 40} \mathrm{Ca}, \mathrm{Sr} / \mathrm{Ca}$ ratios, and $\delta^{26} \mathrm{Mg}$ values may reflect temporal changes in the style of early dolomitisation/diagenesis (fluid- and sediment-buffered) and not necessarily changes in the $\delta^{13} \mathrm{C}$ values of dissolved inorganic carbon (DIC) in global seawater.

$\mathrm{The} \mathrm{Sr} / \mathrm{Ca}$ ratio in carbonates has long been a subject of investigation because its partitioning into carbonate minerals is controlled by several factors, such as carbonate mineralogy (e.g., Kinsman, 1969), paleo sea surface temperatures (e.g., Smith et al., 1979; Rosenthal et al., 1997; Gagan et al., 1998), productivity (e.g., Weinbauer and Velimirov, 1995; Stoll and Schrag, 2000; 
Stoll and Schrag, 2001), sea-level change (Stoll and Schrag, 1998), and fluid geochemistry (Langer et al., 2006). Here, we focus on the breadth of research that indicates that $\mathrm{Sr} / \mathrm{Ca}$ variability is a signature of carbonate recrystallization (e.g., Kinsman, 1969; Brand and Veizer, 1980; Richter and Liang, 1993; Stoll and Schrag, 1998; Fantle and DePaolo, 2006; Tang et al., 2008a).

To illustrate the potential of coupling $\delta^{44 / 40} \mathrm{Ca}$ with $\mathrm{Sr} / \mathrm{Ca}$, arrays of $\delta^{44 / 40} \mathrm{Ca}$ values and $\mathrm{Sr} / \mathrm{Ca}$ ratios in the bulk carbonate rock record (Fig. 3) are not readily explained by changes in seawater $\delta^{44 / 40} \mathrm{Ca}$ and $\mathrm{Sr} / \mathrm{Ca}$ values (e.g., Lau et al., 2017). Instead, the overall inverse relationship is more likely related to combined effects of fluid- and sediment-buffered diagenesis and variations in carbonate mineralogy (Husson et al., 2015; Lau et al., 2017; Ahm et al., 2018). This relationship is most evident for $\delta^{44 / 40} \mathrm{Ca}$ and $\mathrm{Sr} / \mathrm{Ca}$ data from the Precambrian, and for time intervals with aragonite-dominated $\mathrm{CaCO}_{3}$ precipitation inferred by changing seawater $\mathrm{Mg} / \mathrm{Ca}$ ("aragonite seas," Hardie, 1996). This trend agrees with the observation that aragonite tends to have lower $\delta^{44 / 40} \mathrm{Ca}$ values and higher $\mathrm{Sr} / \mathrm{Ca}$ ratios (Gussone et al., 2005; Kinsman, 1969), and that recrystallization would result in higher $\delta^{44 / 40} \mathrm{Ca}$ values and lower $\mathrm{Sr} / \mathrm{Ca}$ ratios with greater fluid-rock interaction. Because the aragonite-sea data are dominated by intervals with known volcanic $\mathrm{CO}_{2}$ perturbations, it is possible that a sampling bias results in common trends. However, the similarity to the Precambrian data may indicate common drivers.

In contrast, the relationship between bulk carbonate $\delta^{44 / 40} \mathrm{Ca}$ values and $\mathrm{Sr} / \mathrm{Ca}$ ratios for time intervals with calcite-dominated $\mathrm{CaCO}_{3}$ precipitation show greater variability (Fig. 3). Indeed, a significant positive correlation is observed for a carbonate-poor PETM deep-sea core (Griffith et al., 2015), which may indicate that a unique diagenetic regime characterizes predominantly siliciclastic $\delta^{44 / 40} \mathrm{Ca}$ records. Data from the Late Silurian exhibit a linear inverse relationship between $\delta^{44 / 40} \mathrm{Ca}$ and $\mathrm{Sr} / \mathrm{Ca}$, potentially reflecting variable precipitation rates and not diagenesis (Farkaš et al., 2016). Because aragonite precipitation is not as dominant in times of calcite seas, it is possible that other factors, besides the aragonite diagenetic pathway, are being observed. 
Nonetheless, the range in $\delta^{44 / 40} \mathrm{Ca}$ values and $\mathrm{Sr} / \mathrm{Ca}$ ratios for calcite seas is generally comparable to data for aragonite seas. Besides the overlapping $\delta^{44 / 40} \mathrm{Ca}$ ranges of the different $\mathrm{Ca}$ carbonates, it can also reflect the potential for aragonite to still precipitate in calcite seas, likely because individual taxa do not change the mineralogy of their biogenic carbonate production despite changing seawater $\mathrm{Mg} / \mathrm{Ca}$ (Kimmig and Holmden et al., 2017).

The range in $\delta^{44 / 40} \mathrm{Ca}$ values that result from variations in carbonate mineralogy and rate-dependent $\mathrm{Ca}$ isotope fractionation during diagenesis are significantly larger than plausible changes in seawater $\delta^{44 / 40} \mathrm{Ca}$ values associated with transient perturbations to the global $\mathrm{Ca}$ cycle (Blättler and Higgins, 2017; Husson et al., 2015; Komar and Zeebe, 2016). Therefore, large stratigraphic changes in $\delta^{44 / 40} \mathrm{Ca}$ values, that covary with other carbonate bound proxies may not only reflect changes in global weathering rates or other Ca cycle imbalances (e.g., Kasemann et al., 2014, 2005; Silva-Tamayo et al., 2010). Instead, it is likely that large stratigraphic changes in $\delta^{44 / 40} \mathrm{Ca}$ values are associated with changes in carbonate mineralogy and diagenesis (fluid- and sediment-buffered). For example, large stratigraphic changes in both $\delta^{44 / 40} \mathrm{Ca}$ values and $\mathrm{Sr}$ concentrations that are consistent with sediment-buffered preservation of former aragonite has been observed across the Permian-Triassic boundary (Lau et al., 2017), the Late Silurian (Farkaš et al., 2016), the end-Ordovician glaciation (Holmden et al., 1998; Kimmig and Holmden, 2017; Jones et al., 2020), the Ediacaran Shuram excursion (Husson et al., 2015), and the Marinoan cap carbonate sequence (Ahm et al., 2019) (see section 3.2 for more details). Although this new application of $\mathrm{Ca}$ isotopes is distinct from initial interpretations, bulk carbonate $\delta^{44 / 40} \mathrm{Ca}$ is emerging as a new tool for evaluating diagenetic processes and $\mathrm{CaCO}_{3}$ mineralogy for a depositional environment — conditions that have been difficult to characterize using other methods. 
Due to the increasing number of unknown variables - particularly as one investigates further back in geologic time - obtaining meaningful environmental or geological information through Earth's history presents unique challenges that can be probed using $\mathrm{Ca}$ isotopes. Here we have highlighted several different processes that affect the $\mathrm{Ca}$ isotope composition of seawater, and in addition, the $\delta^{44 / 40} \mathrm{Ca}$ of different archives. For bulk sediment data, each record is unique in terms of age, coeval ocean chemistry, paleogeography, sediment composition, depositional and diagenetic history, availability of archives and preservation. Consequently, the approaches for using $\mathrm{Ca}$ isotopes for both skeletal and non-skeletal carbonate archives has evolved in the last several decades, as the growing body of research has led to the re-evaluation of fundamental assumptions about the factors driving Ca isotope variability that guide how this proxy is applied and interpreted. Taking these aspects into consideration, $\mathrm{Ca}$ isotope variability has a great potential to shed new light into the evolution of the Earth system in deep time, as well as the diagenetic pathway of the carbonate rocks that record the geochemical clues that can be used to address these questions.

\section{Acknowledgements}

The authors thank Elizabeth Griffith and Matthew Fantle for their leadership in spearheading this special issue. We are grateful to Andrew Jacobson and four anonymous reviewers, and editors Matthew Fantle and Jerome Gaillardet, for their combined constructive comments and the editorial handling. This work was supported by: the Simons Foundation (SCOL 611878) to ACA, Natural Environment Research Council (NE/R013519/1) to HJB, the Deutsche Forschungsgemeinschaft (GU1035/5) to NG.

\section{References}


Ahm, A.-S.C., Bjerrum, C.J., Blättler, C.L., Swart, P.K., Higgins, J.A., 2018. Quantifying early marine diagenesis in shallow-water carbonate sediments. Geochimica et Cosmochimica Acta 236, 140-159. https://doi.org/10.1016/j.gca.2018.02.042

Ahm, A.-S.C., Maloof, A.C., Macdonald, F.A., Hoffman, P.F., Bjerrum, C.J., Bold, U., Rose, C.V., Strauss, J.V., Higgins, J.A., 2019. An early diagenetic deglacial origin for basal Ediacaran "cap dolostones." Earth and Planetary Science Letters 506, 292-307. https://doi.org/10.1016/j.eps1.2018.10.046

AlKhatib, M., Eisenhauer, A., 2017a. Calcium and strontium isotope fractionation in aqueous solutions as a function of temperature and reaction rate; I. Calcite. Geochimica et Cosmochimica Acta 209, 296-319. https://doi.org/10.1016/j.gca.2016.09.035

AlKhatib, M., Eisenhauer, A., 2017b. Calcium and strontium isotope fractionation during precipitation from aqueous solutions as a function of temperature and reaction rate; II. Aragonite. Geochimica et Cosmochimica Acta 209, 320-342. https://doi.org/10.1016/j.gca.2017.04.012

Amini, M., Eisenhauer, A., Böhm, F., Fietzke, J., Bach, W., Garbe-Schönberg, D., Rosner, M., Bock, B., Lackschewitz, K.S., Hauff, F., 2008. Calcium isotope $\left(\delta^{44 / 40} \mathrm{Ca}\right)$ fractionation along hydrothermal pathways, Logatchev field (Mid-Atlantic Ridge, $14^{\circ} 45^{\prime} \mathrm{N}$ ). Geochimica et Cosmochimica Acta 72, 4107-4122. https://doi.org/10.1016/j.gca.2008.05.055

Antonelli, M.A., Brown, S.T., Simon, J.I., this issue. Calcium isotopes in high-temperature terrestrial processes. Chemical Geology.

Antonelli, M., DePaolo, D., Brown, S. Pester, N., 2018. Radiogenic ${ }^{40}$ Ca in Modern Seawater, Goldschmidt Abstracts, 201871.

Archer, D., 2005. Fate of fossil fuel $\mathrm{CO}_{2}$ in geologic time. Journal of Geophysical Research: Oceans 110. https://doi.org/10.1029/2004JC002625

Arning, E.T., Lückge, A., Breuer, C., Gussone, N., Birgel, D., Peckmann, J., 2009. Genesis of phosphorite crusts off Peru. Marine Geology 262, 68-81.

Baadsgaard, H., 1987. Rb-Sr and K-Ca isotope systematics in minerals from potassium horizons in the prairie evaporite formation, Saskatchewan, Canada. Chemical Geology 66, 1-15. https://doi.org/10.1016/0168-9622(87)90022-4

Bermingham, K.R., Gussone, N., Mezger, K., Krause, J., 2018. Origins of mass-dependent and mass-independent $\mathrm{Ca}$ isotope variations in meteoritic components and meteorites. Geochimica et Cosmochimica Acta 226, 206-223. https://doi.org/10.1016/j.gca.2018.01.034

Berner, R.A., 2004. A model for calcium, magnesium and sulfate in seawater over Phanerozoic time. Am J Sci 304, 438-453. https://doi.org/10.2475/ajs.304.5.438

Bjerrum, C.J., Canfield, D.E., 2011. Towards a quantitative understanding of the late Neoproterozoic carbon cycle. PNAS 108, 5542-5547. https://doi.org/10.1073/pnas.1101755108

Blättler, C.L., Stanley, S.M., Henderson, G.M., Jenkyns, H.C., 2014. Identifying vital effects in Halimeda algae with Ca isotopes. Biogeosciences 11, 7207-7217.

Blättler, C.L., Claire, M.W., Prave, A.R., Kirsimäe, K., Higgins, J.A., Medvedev, P.V., Romashkin, A.E., Rychanchik, D.V., Zerkle, A.L., Paiste, K., Kreitsmann, T., Millar, I.L., Hayles, 
J.A., Bao, H., Turchyn, A.V., Warke, M.R., Lepland, A., 2018. Two-billion-year-old evaporites capture Earth's great oxidation. Science 360, 320-323. https://doi.org/10.1126/science.aar2687

Blättler, C.L., Henderson, G.M., Jenkyns, H.C., 2012. Explaining the Phanerozoic Ca isotope history of seawater. Geology 40, 843-846. https://doi.org/10.1130/G33191.1

Blättler, C.L., Higgins, J.A., 2017. Testing Urey's carbonate-silicate cycle using the calcium isotopic composition of sedimentary carbonates. Earth and Planetary Science Letters 479, 241251. https://doi.org/10.1016/j.eps1.2017.09.033

Blättler, C.L., Higgins, J.A., 2014. Calcium isotopes in evaporites record variations in Phanerozoic seawater SO4 and Ca. Geology 42, 711-714. https://doi.org/10.1130/G35721.1

Blättler, C.L., Jenkyns, H.C., Reynard, L.M., Henderson, G.M., 2011. Significant increases in global weathering during Oceanic Anoxic Events 1a and 2 indicated by calcium isotopes. Earth and Planetary Science Letters 309, 77-88. https://doi.org/10.1016/j.epsl.2011.06.029

Blättler, C.L., Kump, L.R., Fischer, W.W., Paris, G., Kasbohm, J.J., Higgins, J.A., 2017. Constraints on ocean carbonate chemistry and $\mathrm{pCO}_{2}$ in the Archaean and Palaeoproterozoic. Nature Geosci 10, 41-45. https://doi.org/10.1038/ngeo2844

Blättler, C.L., Miller, N.R., Higgins, J.A., 2015. Mg and Ca isotope signatures of authigenic dolomite in siliceous deep-sea sediments. Earth and Planetary Science Letters 419, 32-42. https://doi.org/10.1016/j.epsl.2015.03.006

Blättler, C.L., Higgins, J.A., Swart, P. K., 2019. Advected glacial seawater preserved in the subsurface of the Maldives carbonate edifice. Geochimica et Cosmochimica Acta 257, 80-95 https://doi.org/10.1016/j.gca.2019.04.030

Blättler, C.L., Bergmann, K.D., Kah, L.C., Gómez-Pérez, I., Higgins, J.A., 2020. Constraints on Meso- to Neoproterozoic seawater from ancient evaporite deposits. Earth and Planetary Science Letters 532, 115951. https://doi.org/10.1016/j.eps1.2019.115951

Böhm, F., Gussone, N., Eisenhauer, A., Dullo, W.-C., Reynaud, S., Paytan, A., 2006. Calcium isotope fractionation in modern scleractinian corals. Geochimica et Cosmochimica Acta 70, 4452-4462. https://doi.org/10.1016/j.gca.2006.06.1546

Bradbury, H.J., Turchyn, A.V., 2018. Calcium isotope fractionation in sedimentary pore fluids from ODP Leg 175: Resolving carbonate recrystallization. Geochimica et Cosmochimica Acta 236, 121-139. https://doi.org/10.1016/j.gca.2018.01.040

Brand, U., Veizer, J., 1980. Chemical Diagenesis of a Multicomponent Carbonate System--I: Trace Elements. Journal of Sedimentary Petrology 50, 1219-136.

Brazier, J.-M., Suan, G., Tacail, T., Simon, L., Martin, J.E., Mattioli, E., Balter, V., 2015. Calcium isotope evidence for dramatic increase of continental weathering during the Toarcian oceanic anoxic event (Early Jurassic). Earth and Planetary Science Letters 411, 164-176. https://doi.org/10.1016/j.eps1.2014.11.028

Broecker, W.S., Peng, Z., Lamont-Doherty Geological Observatory, 1982. Tracers in the sea. Lamont-Doherty Geological Observatory, Columbia University, Palisades, N.Y.

Broecker, W. and Takahashi, T., 1966. Calcium carbonate precipitation on the Great Bahama Banks. Journal of Geophysical Research. 71. 10.1029/JZ071i006p01575. 
Burgess, S.D., Bowring, S., Shen, S., 2014. High-precision timeline for Earth's most severe extinction. PNAS 111, 3316-3321. https://doi.org/10.1073/pnas.1317692111

Caro, G., Papanastassiou, D.A., Wasserburg, G.J., $2010 .{ }^{40} \mathrm{~K}-{ }^{40} \mathrm{Ca}$ isotopic constraints on the oceanic calcium cycle. Earth and Planetary Science Letters 296, 124-132. https://doi.org/10.1016/j.eps1.2010.05.001

Cecil, M.R., Ducea, M.N., 2011. K-Ca ages of authigenic sediments: examples from Paleozoic glauconite and applications to low-temperature thermochronometry. Int J Earth Sci (Geol Rundsch) 100, 1783-1790. https://doi.org/10.1007/s00531-010-0618-y

Chakrabarti, R., Mondalm, S., Jacobson, A.D., Mills, M., Romaniello, S.J., Vollstaedt, H., this issue. Techniques, challenges, new developments, and the way forward for calcium isotope measurements, Chem. Geol.

Chen X., Deng W., Zhu H., Zhang Z., Wei G. and McCulloch M. T., 2016. Assessment of coral $\delta^{44 / 40} \mathrm{Ca}$ as a paleoclimate proxy in the Great Barrier Reef of Australia. Chem. Geol. 435, 7178.

Cox, G.M., Halverson, G.P., Stevenson, R.K., Votkaty, M, Poirier, A., Kunzmann, M., Li, Z.X., Denyszyn, S.W., Strauss, J.V., Macdonald, F.A., 2016. Continental flood basalt weathering as a trigger for Neoproterozoic Snowball Earth Earth and Planetary Science Letters 446, 89-99

Colla, C.A., Wimpenny, J., Yin, Q.-Z., Rustad, J.R., Casey, W.H., 2013. Calcium-isotope fractionation between solution and solids with six, seven or eight oxygens bound to $\mathrm{Ca}$ (II). Geochimica et Cosmochimica Acta 121, 363-373. https://doi.org/10.1016/j.gca.2013.07.041

Coplen, T.B., Böhlke, J.K., De, B.P., Ding, T., Holden, N.E., Hopple, J.A., Krouse, H.R., Lamberty, A., Peiser, H.S., Revesz, K., Rieder, S.E., Rosman, K.J.R., Roth, E., Taylor, P.D.P., Vocke, R.D., Xiao, Y.K., 2002. Isotope-abundance variations of selected elements (IUPAC Technical Report). Pure and Applied Chemistry 74, 1987-2017. https://doi.org/10.1351/pac200274101987

Cui, Y., Kump, L., Ridgwell, A., 2015. Spatial and temporal patterns of ocean acidification during the end-Permian mass extinction-an earth system model evaluation. Volcanism and Global Environmental Change 291-307. https://doi.org/10.1007/9781107415683.020

De La Rocha, C.L., DePaolo, D.J., 2000. Isotopic evidence for variations in the marine calcium cycle over the Cenozoic. Science 289, 1176-8.

DePaolo, D.J., 2011. Surface kinetic model for isotopic and trace element fractionation during precipitation of calcite from aqueous solutions. Geochimica et Cosmochimica Acta 75, 10391056. https://doi.org/10.1016/j.gca.2010.11.020

DePaolo, D.J., Kyte, F.T., Marshall, B.D., O’Neil, J.R., Smit, J., 1983. Rb-Sr, Sm-Nd, K-Ca, $\mathrm{O}$, and $\mathrm{H}$ isotopic study of Cretaceous-Tertiary boundary sediments, Caravaca, Spain: evidence for an oceanic impact site. Earth and Planetary Science Letters 64, 356-373. https://doi.org/10.1016/0012-821X(83)90096-1

Derry, L.A., 2010. A burial diagenesis origin for the Ediacaran Shuram-Wonoka carbon isotope anomaly. Earth and Planetary Science Letters 294, 152-162. https://doi.org/10.1016/j.eps1.2010.03.022 
Dietzel, M., Gussone, N., Eisenhauer, A., 2004. Co-precipitation of $\mathrm{Sr}^{2+}$ and $\mathrm{Ba}^{2+}$ with aragonite by membrane diffusion of $\mathrm{CO}_{2}$ between 10 and $50{ }^{\circ} \mathrm{C}$. Chemical Geology 203, 139-151. https://doi.org/10.1016/j.chemgeo.2003.09.008

Du Vivier, A.D.C., Jacobson, A.D., Lehn, G.O., Selby, D., Hurtgen, M.T., Sageman, B.B., 2015. Ca isotope stratigraphy across the Cenomanian-Turonian OAE 2: Links between volcanism, seawater geochemistry, and the carbonate fractionation factor. Earth and Planetary Science Letters 416, 121-131. https://doi.org/10.1016/j.epsl.2015.02.001

Erhardt, A.M., Turchyn, A.V., Bradbury, H.J., Dickson, J.A.D., this issue. The calcium isotopic composition of carbonate hardground cements: A new record of changes in ocean chemistry? Chemical Geology.

Erhardt, A. M., Turchyn, A. V., Dickson, J. A. D., Sadekov, A. Y., Tayler, P. D., Wilson, M. A., Schrag, D. P., in review. Chemical composition of carbonate hardground cements as reconstructive tools for Phanerzoic pore fluid. Geochemistry, Geophysics, Geosystems.

Ewing, S., Yang, W., DePaolo, D.J., Michalski, G., Kendall, C., Stewart, B., Thiemens, M., Amundson, R. (2008) Non-biological Fractionation of Stable Ca Isotopes in Soils of the Atacama Desert, Chile, Geochimica et Cosmochimica Acta, 72 (4), 1096-1110.

Fantle, M.S., 2010. Evaluating the Ca isotope proxy. Am. J. Sci. 310, 194-230.

Fantle, M.S., Tollerud, H., Eisenhauer, A., Holmden, C., 2012. The Ca isotopic composition of dust-producing regions: measurements of surface sediments in the Black Rock Desert, Nevada. Geochim. Cosmochim. Acta 87, 178-193.

Fantle, M.S., 2015. Calcium isotopic evidence for rapid recrystallization of bulk marine carbonates and implications for geochemical proxies. Geochimica et Cosmochimica Acta 148, 378-401. https://doi.org/10.1016/j.gca.2014.10.005

Fantle, M.S., DePaolo, D.J., 2007. Ca isotopes in carbonate sediment and pore fluid from ODP Site 807A: The $\mathrm{Ca}^{2+}(\mathrm{aq})-$ calcite equilibrium fractionation factor and calcite recrystallization rates in Pleistocene sediments. Geochimica et Cosmochimica Acta 71, 2524-2546. https://doi.org/10.1016/j.gca.2007.03.006

Fantle, M.S., DePaolo, D.J., 2005. Variations in the marine Ca cycle over the past 20 million years. Earth and Planetary Science Letters 237, 102-117. https://doi.org/10.1016/j.eps1.2005.06.024

Fantle, M.S., Higgins, J., 2014. The effects of diagenesis and dolomitization on $\mathrm{Ca}$ and $\mathrm{Mg}$ isotopes in marine platform carbonates: Implications for the geochemical cycles of $\mathrm{Ca}$ and $\mathrm{Mg}$. Geochimica et Cosmochimica Acta 142, 458-481. https://doi.org/10.1016/j.gca.2014.07.025

Fantle, M.S., Tipper, E.T., 2014. Calcium isotopes in the global biogeochemical Ca cycle: Implications for development of a $\mathrm{Ca}$ isotope proxy. Earth-Science Reviews 129, 148-177. https://doi.org/10.1016/j.earscirev.2013.10.004

Farkaš, J., Böhm, F., Wallmann, K., Blenkinsop, J., Eisenhauer, A., van Geldern, R., Munnecke, A., Voigt, S., Veizer, J., 2007a. Calcium isotope record of Phanerozoic oceans: Implications for chemical evolution of seawater and its causative mechanisms. Geochimica et Cosmochimica Acta 71, 5117-5134. https://doi.org/10.1016/j.gca.2007.09.004 
Farkaš, J., Buhl, D., Blenkinsop, J., Veizer, J., 2007b. Evolution of the oceanic calcium cycle during the late Mesozoic: Evidence from $\delta^{44 / 40} \mathrm{Ca}$ of marine skeletal carbonates. Earth and Planetary Science Letters 253, 96-111. https://doi.org/10.1016/j.epsl.2006.10.015

Farkaš, J., Dejeant, A., Novak, M., Jacobson, S.B., 2011. Calcium isotope constraints on the uptake and sources of $\mathrm{Ca}^{2+}$ in a base-poor forest: A new concept of combining stable $\left(\delta^{44 / 42} \mathrm{Ca}\right)$ and radiogenic $\left(\mathrm{e}_{\mathrm{Ca}}\right.$ ) signals. Geochim Cosmochim Acta 75, 7031-7046.

Farkaš, J., Frýda, J., Holmden, C., 2016. Calcium isotope constraints on the marine carbon cycle and $\mathrm{CaCO}_{3}$ deposition during the late Silurian (Ludfordian) positive $\delta^{13} \mathrm{C}$ excursion. Earth and Planetary Science Letters 451, 31-40. https://doi.org/10.1016/j.eps1.2016.06.038

Fletcher, I.R., McNaughton, N.J., Pidgeon, R.T., Rosman, K.J.R., 1997. Sequential closure of $\mathrm{K}-\mathrm{Ca}$ and $\mathrm{Rb}-\mathrm{Sr}$ isotopic systems in Archaean micas. Chemical Geology 138, 289-301. https://doi.org/10.1016/S0009-2541(97)00005-3

Gagan, M.k., Ayliffe, LK., Hoplry, D., Cali, J.A., Mortimer, G.E., Chapell, J., McCulloch, M.T., Head, M.J., 1998. Temperature and surface ocean water balance of the mid-Holocene tropical western Pacific. Science 279, 1014-1018.

Gopalan, K., Kumar, A., 2008. Phlogopite K-Ca dating of Narayanpet kimberlites, south India: Implications to the discordance between their $\mathrm{Rb}-\mathrm{Sr}$ and $\mathrm{Ar} / \mathrm{Ar}$ ages. Precambrian Research 167, 377-382. https://doi.org/10.1016/j.precamres.2008.09.006

Gothmann, A.M., Bender, M.L., Blättler, C.L., Swart, P.K., Giri, S.J., Adkins, J.F., Stolarski, J., Higgins, J.A., 2016. Calcium isotopes in scleractinian fossil corals since the Mesozoic: Implications for vital effects and biomineralization through time. Earth and Planetary Science Letters 444, 205-214. https://doi.org/10.1016/j.eps1.2016.03.012

Gothmann, A.M., Stolarski, J., Adkins, J.F., Schoene, B., Dennis, K.J., Schrag, D.P., Mazur, M., Bender, M.L., 2015. Fossil corals as an archive of secular variations in seawater chemistry since the Mesozoic. Geochimica et Cosmochimica Acta 160, 188-208. https://doi.org/10.1016/j.gca.2015.03.018

Griffith, E.M., Fantle, M.S., Eisenhauer, A., Paytan, A., Bullen, T.D., 2015. Effects of ocean acidification on the marine calcium isotope record at the Paleocene-Eocene Thermal Maximum. Earth and Planetary Science Letters 419, 81-92. https://doi.org/10.1016/j.eps1.2015.03.010

Griffith, E.M., Paytan, A., Caldeira, K., Bullen, T.D., Thomas, E., 2008a. A Dynamic Marine Calcium Cycle During the Past 28 Million Years. Science 322, 1671-1674. https://doi.org/10.1126/science. 1163614

Griffith, E.M., Paytan, A., Eisenhauer, A., Bullen, T.D., Thomas, E., 2011. Seawater calcium isotope ratios across the Eocene-Oligocene transition. Geology 39, 683-686. https://doi.org/10.1130/G31872.1

Griffith, E.M., Paytan, A., Kozdon, R., Eisenhauer, A., Ravelo, A.C., 2008b. Influences on the fractionation of calcium isotopes in planktonic foraminifera. Earth and Planetary Science Letters 268, 124-136. https://doi.org/10.1016/j.eps1.2008.01.006

Griffith, E.M., Schmitt, A.-D., Andrews, M.G., Fantle, M.S., this issue. Elucidating geochemical cycles at local, regional and global scales using calcium isotopes. Chemical Geology. 
Gussone, N., Eisenhauer, A., Tiedemann, R., Haug, G.H., Heuser, A., Bock, B., Nägler, Th.F. and Müller, A., 2004. $\delta^{44} \mathrm{Ca}, \delta^{18} \mathrm{O}$ and $\mathrm{Mg} / \mathrm{Ca}$ Reveal Caribbean Sea Surface Temperature and Salinity Fluctuations During the Pliocene Closure of the Central-American Gateway. Earth and Planetary Science Letters 227, 201-214.

Gussone, N., Böhm, F., Eisenhauer, A., Dietzel, M., Heuser, A., Teichert, B.M.A., Reitner, J., Wörheide, G., Dullo, W.-C., 2005. Calcium isotope fractionation in calcite and aragonite. Geochimica et Cosmochimica Acta 69, 4485-4494. https://doi.org/10.1016/j.gca.2005.06.003

Gussone, N., Eisenhauer, A., Heuser, A., Dietzel, M., Bock, B., Böhm, F., Spero, H.J., Lea, D.W., Bijma, J., Nägler, T.F., 2003. Model for kinetic effects on calcium isotope fractionation $\left(\delta^{44} \mathrm{Ca}\right)$ in inorganic aragonite and cultured planktonic foraminifera. Geochimica et Cosmochimica Acta 67, 1375-1382. https://doi.org/10.1016/S0016-7037(02)01296-6

Gussone, N., Filipsson, H.L., 2010. Calcium isotope ratios in calcitic tests of benthic foraminifers. Earth and Planetary Science Letters 290, 108-117. https://doi.org/10.1016/j.epsl.2009.12.010

Gussone, N., Friedrich, O., 2018. Cretaceous calcareous dinoflagellate cysts as recorder of $\delta^{44 / 40} \mathrm{Ca}_{\text {seawater }}$ and paleo-temperature using $\mathrm{Sr} / \mathrm{Ca}$ thermometry. Chemical Geology 488, 138 148. https://doi.org/10.1016/j.chemgeo.2018.04.020

Gussone, N., Greifelt, T., 2019. Incorporation of Ca isotopes in carapaxes of marine ostracods. Chemical Geology 510, 130-139. https://doi.org/10.1016/j.chemgeo.2019.02.012

Gussone, N., Heuser, A., 2016. Biominerals and Biomaterial, in: Gussone, N., Schmitt, A.-D., Heuser, A., Wombacher, F., Dietzel, M., Tipper, E., Schiller, M. (Eds.), Calcium Stable Isotope Geochemistry, Advances in Isotope Geochemistry. Springer Berlin Heidelberg, Berlin, Heidelberg, pp. 111-144. https://doi.org/10.1007/978-3-540-68953-9_4

Gussone, N., Hönisch, B., Heuser, A., Eisenhauer, A., Spindler, M., Hemleben, C., 2009. A critical evaluation of calcium isotope ratios in tests of planktonic foraminifers. Geochimica et Cosmochimica Acta 73, 7241-7255. https://doi.org/10.1016/j.gca.2009.08.035

Gussone, N., Langer, G., Geisen, M., Steel, B.A., Riebesell, U., 2007. Calcium isotope fractionation in coccoliths of cultured Calcidiscus leptoporus, Helicosphaera carteri, Syracosphaera pulchra and Umbilicosphaera foliosa. Earth and Planetary Science Letters 260, 505515. https://doi.org/10.1016/j.eps1.2007.06.001

Gussone, N., Langer, G., Thoms, S., Nehrke, G., Eisenhauer, A., Riebesell, U., Wefer, G., 2006. Cellular calcium pathways and isotope fractionation in Emiliania huxleyi. Geology 34, 625628. https://doi.org/10.1130/G22733.1

Gussone, N., Nehrke, G., Teichert, B.M.A., 2011. Calcium isotope fractionation in ikaite and vaterite. Chemical Geology 285, 194-202. https://doi.org/10.1016/j.chemgeo.2011.04.002

Gussone, N., Zonneveld, K., Kuhnert, H., 2010. Minor element and Ca isotope composition of calcareous dinoflagellate cysts of cultured Thoracosphaera heimii. Earth and Planetary Science Letters 289, 180-188. https://doi.org/10.1016/j.eps1.2009.11.006

Halverson, G.P., Hoffman, P.F., Schrag, D.P., Maloof, A.C., Rice, A.H.N., 2005. Toward a Neoproterozoic composite carbon-isotope record. GSA Bulletin 117, 1181-1207. https://doi.org/10.1130/B25630.1 
Hardie, L.A., 1996. Secular variation in seawater chemistry: An explanation for the coupled secular variation in the mineralogies of marine limestones and potash evaporites over the past 600 m.y. Geology 24, 279-283.

Harouaka, K., 2011. An Investigation of the Mechanisms of Calcium Isotopic Fractionation in Gypsum.

Harouaka, K., Eisenhauer, A., Fantle, M.S., 2014. Experimental investigation of Ca isotopic fractionation during abiotic gypsum precipitation. Geochimica et Cosmochimica Acta 129, 157-176. https://doi.org/10.1016/j.gca.2013.12.004

Haynes, W.M., Lide, D.R., Bruno, T.J., 2017. CRC Handbook of Chemistry and Physics, 97th edn, Vol. 2016-2017. CRC Press.

Hensley, T.M., 2006. Calcium Isotopic Variation in Marine Evaporites and Carbonates: Applications to Late Miocene Mediterranean Brine Chemistry and Late Cenozoic Calcium Cycling in the Oceans. Scripps Institution of Oceanography.

Heumann, K.G., Kubassek, E., Schwabenbauer, W., Stadler, I., 1979. Analytical method for the K/Ca age determination of geological samples. Z. Anal. Chem 297, 35-43.

Heuser, A., 2016. Biomedical Application of Ca Stable Isotopes, in: Gussone, N., Schmitt, A.D., Heuser, A., Wombacher, F., Dietzel, M., Tipper, E., Schiller, M. (Eds.), Calcium Stable Isotope Geochemistry, Advances in Isotope Geochemistry. Springer Berlin Heidelberg, Berlin, Heidelberg, pp. 247-260. https://doi.org/10.1007/978-3-540-68953-9_8

Heuser, A., Eisenhauer, A., Böhm, F., Wallmann, K., Gussone, N., Pearson, P.N., Nägler, T.F., Dullo, W.-C., 2005. Calcium isotope $\left(\delta^{44 / 40} \mathrm{Ca}\right)$ variations of Neogene planktonic foraminifera. Paleoceanography 20. https://doi.org/10.1029/2004PA001048

Higgins, J.A., Blättler, C.L., Lundstrom, E.A., Santiago-Ramos, D.P., Akhtar, A.A., Crüger Ahm, A.-S., Bialik, O., Holmden, C., Bradbury, H., Murray, S.T., Swart, P.K., 2018. Mineralogy, early marine diagenesis, and the chemistry of shallow-water carbonate sediments. Geochimica et Cosmochimica Acta 220, 512-534. https://doi.org/10.1016/j.gca.2017.09.046

Hinojosa, J.L., Brown, S.T., Chen, J., DePaolo, D.J., Paytan, A., Shen, S., Payne, J.L., 2012. Evidence for end-Permian ocean acidification from calcium isotopes in biogenic apatite. Geology 40, 743-746. https://doi.org/10.1130/G33048.1

Hippler, D., Eisenhauer, A., Nägler, T.F., 2006. Tropical Atlantic SST history inferred from Ca isotope thermometry over the last 140ka. Geochimica et Cosmochimica Acta 70, 90-100. https://doi.org/10.1016/j.gca.2005.07.022

Hippler, D., Kozdon, R., Darling, K.F., Eisenhauer, A., Nagler, T.F., 2009. Calcium isotopic composition of high-latitude proxy carrier Neogloboquadrina pachyderma (sin.). Biogeosciences $6,1-14$.

Hippler, D., Witbaard, R., van Aken, H.M., Buhl, D., Immenhauser, A., 2013. Exploring the calcium isotope signature of Arctica islandica as an environmental proxy using laboratory- and field-cultured specimens. Palaeogeography, Palaeoclimatology, Palaeoecology 373, 75-87. https://doi.org/10.1016/j.palaeo.2011.11.015 
Hiebenthal, C., 2009. Sensitivity of A. islandica and M. edulis towards environmental changes: a threat to the bivalves - an opportunity for palaeo-climatology? PhD thesis, Christian-Albrechts-Universität Kiel, pp 1-138

Hoffman, P.F., Schrag, D.P., 2002. The snowball Earth hypothesis: testing the limits of global change. Terra Nova 14, 129-155. https://doi.org/10.1046/j.1365-3121.2002.00408.x

Holmden, C., 2009. Ca isotope study of Ordovician dolomite, limestone, and anhydrite in the Williston Basin: Implications for subsurface dolomitization and local Ca cycling. Chemical Geology 268, 180-188. https://doi.org/10.1016/j.chemgeo.2009.08.009

Holmden, C., Creaser, R.A., Muehlenbachs, K., Leslie, S.A., Bergström, S.M., 1998. Isotopic evidence for geochemical decoupling between ancient epeiric seas and bordering oceans: Implications for secular curves. Geology 26, 567-570.

Holmden, C., Panchuk, K., Finney, S.C., 2012. Tightly coupled records of Ca and C isotope changes during the Hirnantian glaciation event in an epeiric sea setting. Geochimica et Cosmochimica Acta 98, 94-106. https://doi.org/10.1016/j.gca.2012.09.017

Huang, S., Farkaš, J. and Jacobsen, S.B., 2010. Calcium isotopic fractionation between clinopyroxene and orthopyroxene from mantle peridotites. Earth Planet. Sci. Lett. 292, 337-344.

Huber, C., Druhan, J.L., Fantle, M.S., 2017. Perspectives on geochemical proxies: The impact of model and parameter selection on the quantification of carbonate recrystallization rates. Geochimica et Cosmochimica Acta 217, 171-192. https://doi.org/10.1016/j.gca.2017.08.023

Husson, J.M., Higgins, J.A., Maloof, A.C., Schoene, B., 2015. Ca and Mg isotope constraints on the origin of Earth's deepest C excursion. Geochimica et Cosmochimica Acta 160, 243-266. https://doi.org/10.1016/j.gca.2015.03.012

Immenhauser, A., Nägler, T.F., Steuber, T., Hippler, D., 2005. A critical assessment of mollusk ${ }^{18} \mathrm{O} /{ }^{16} \mathrm{O}, \mathrm{Mg} / \mathrm{Ca}$, and ${ }^{44} \mathrm{Ca} /{ }^{40} \mathrm{Ca}$ ratios as proxies for Cretaceous seawater temperature seasonality. Palaeogeography, Palaeoclimatology, Palaeoecology 215, 221-237. https://doi.org/10.1016/j.palaeo.2004.09.005

Inoue, M., Nakamura, T., Tanaka, Y., Shinzato, C., Suzuki, A., Yokoyama, Y., Kawahata, H., Sakai, K., Gussone, N. (2018) A simple role of coral-algal symbiosis in coral calcification, Geochimica et Cosmochimica Acta 235,76-76-88.

Inoue, M., Gussone, N., Koga, Y., Iwase, A., Suzuki, A., Sakai, K., Kawahata, H., 2015. Controlling factors of $\mathrm{Ca}$ isotope fractionation in scleractinian corals evaluated by temperature, $\mathrm{pH}$ and light controlled culture experiments. Geochimica et Cosmochimica Acta 167, 80-92. https://doi.org/10.1016/j.gca.2015.06.009

Jacobson, A.D., Holmden, C., 2008. $\delta^{44} \mathrm{Ca}$ evolution in a carbonate aquifer and its bearing on the equilibrium isotope fractionation factor for calcite. Earth and Planetary Science Letters 270, 349-353. https://doi.org/10.1016/j.epsl.2008.03.039

Jacobson, A.D., Grace Andrews, M., Lehn, G.O., Holmden, C., 2015. Silicate versus carbonate weathering in Iceland: New insights from Ca isotopes. Earth and Planetary Science Letters 416, 132-142. https://doi.org/10.1016/j.eps1.2015.01.030 
Jones, D. S., Brothers, R. W., Ahm, A-S. C., Slater, N., Higgins, J. A., Fike, D. A., 2020. Sea level, carbonate mineralogy, and early diagenesis controlled $\delta^{13} \mathrm{C}$ records in Upper Ordovician carbonates. Geology 48, 194-199. https://doi.org/10.1130/G46861.1

Jost, A.B., Bachan, A., Schootbrugge, B. van de, Brown, S.T., DePaolo, D.J., Payne, J.L., 2017. Additive effects of acidification and mineralogy on calcium isotopes in Triassic/Jurassic boundary limestones. Geochemistry, Geophysics, Geosystems 18, 113-124. https://doi.org/10.1002/2016GC006724

Jost, A.B., Mundil, R., He, B., Brown, S.T., Altiner, D., Sun, Y., DePaolo, D.J., Payne, J.L., 2014. Constraining the cause of the end-Guadalupian extinction with coupled records of carbon and calcium isotopes. Earth and Planetary Science Letters 396, 201-212. https://doi.org/10.1016/j.eps1.2014.04.014

Kasemann, S.A., Hawkesworth, C.J., Prave, A.R., Fallick, A.E., Pearson, P.N., 2005. Boron and calcium isotope composition in Neoproterozoic carbonate rocks from Namibia: evidence for extreme environmental change. Earth and Planetary Science Letters 231, 73-86. https://doi.org/10.1016/j.eps1.2004.12.006

Kasemann, S.A., Pogge von Strandmann, P.A.E., Prave, A.R., Fallick, A.E., Elliott, T., Hoffmann, K.-H., 2014. Continental weathering following a Cryogenian glaciation: Evidence from calcium and magnesium isotopes. Earth and Planetary Science Letters 396, 66-77. https://doi.org/10.1016/j.eps1.2014.03.048

Kasemann, S.A., Schmidt, D.N., Pearson, P.N., Hawkesworth, C.J., 2008. Biological and ecological insights into $\mathrm{Ca}$ isotopes in planktic foraminifers as a palaeotemperature proxy. Earth and Planetary Science Letters 271, 292-302. https://doi.org/10.1016/j.eps1.2008.04.007

Kimmig, S.R., Holmden, C., 2017. Multi-proxy geochemical evidence for primary aragonite precipitation in a tropical-shelf 'calcite sea' during the Hirnantian glaciation. Geochimica et Cosmochimica Acta 206, 254-272. https://doi.org/10.1016/j.gca.2017.03.010

Kinsman, D.J.J., 1969. Interpretation of $\mathrm{Sr}^{2+}$ concentrations in carbonate minerals and rocks. Journal of Sedimentary Research 39, 486-508. https://doi.org/10.1306/74D71CB7-2B2111D7-8648000102C1865D

Kisakürek, B., Eisenhauer, A., Böhm, F., Hathorne, E.C., Erez, J., 2011. Controls on calcium isotope fractionation in cultured planktic foraminifera, Globigerinoides ruber and Globigerinella siphonifera. Geochimica et Cosmochimica Acta 75, 427-443. https://doi.org/10.1016/j.gca.2010.10.015

Knauth, L.P., Kennedy, M.J., 2009. The late Precambrian greening of the Earth. Nature 460, 728-732. https://doi.org/10.1038/nature08213

Komar, N., Zeebe, R.E., 2016. Calcium and calcium isotope changes during carbon cycle perturbations at the end-Permian. Paleoceanography 31, 115-130. https://doi.org/10.1002/2015PA002834

Kreissig, K., Elliott, T., 2005. Ca isotope fingerprints of early crust-mantle evolution. Geochimica et Cosmochimica Acta 69, 165-176. https://doi.org/10.1016/j.gca.2004.06.026

Langer, G., Gussone, N., Nehrke, G., Riebesell, U., Eisenhauer, A., Kuhnert, H., Rost, B., Trimborn, S., Thoms, S., 2006. Coccolith strontium to calcium ratios in Emiliana huxleyi: the 
dependence on seawater strontium and calcium concentrations. Limnology and Oceanography 51, 310-320.

Langer, G., Gussone, N., Nehrke, G., Riebesell, U., Eisenhauer, A., Thoms, S., 2007. Calcium isotope fractionation during coccolith formation in Emiliania huxleyi: Independence of growth and calcification rate. Geochemistry, Geophysics, Geosystems 8. https://doi.org/10.1029/2006GC001422

Lau, K.V., Maher, K., Brown, S.T., Jost, A.B., Altıner, D., DePaolo, D.J., Eisenhauer, A., Kelley, B.M., Lehrmann, D.J., Paytan, A., Yu, M., Silva-Tamayo, J.C., Payne, J.L., 2017. The influence of seawater carbonate chemistry, mineralogy, and diagenesis on calcium isotope variations in Lower-Middle Triassic carbonate rocks. Chemical Geology 471, 13-37. https://doi.org/10.1016/j.chemgeo.2017.09.006

Le Houedec, S., McCulloch, M., Trotter, J., Rankenburg, K., 2017. Conodont apatite $\delta^{88 / 86} \mathrm{Sr}$ and $\delta^{44 / 40} \mathrm{Ca}$ compositions and implications for the evolution of Palaeozoic to early Mesozoic seawater. Chemical Geology 453, 55-65. https://doi.org/10.1016/j.chemgeo.2017.02.013

Lemarchand, D., Wasserburg, G.J., Papanastassiou, D.A., 2004. Rate-controlled calcium isotope fractionation in synthetic calcite. Geochimica et Cosmochimica Acta 68, 4665-4678. https://doi.org/10.1016/j.gca.2004.05.029

Marriott, C.S., Henderson, G.M., Belshaw, N.S., Tudhope, A.W., 2004. Temperature dependence of $\delta^{7} \mathrm{Li}, \delta^{44} \mathrm{Ca}$ and $\mathrm{Li} / \mathrm{Ca}$ during growth of calcium carbonate. Earth and Planetary Science Letters 222, 615-624. https://doi.org/10.1016/j.eps1.2004.02.031

Marshall, B.D., DePaolo, D.J., 1989. Calcium isotopes in igneous rocks and the origin of granite. Geochimica et Cosmochimica Acta 53, 917-922. https://doi.org/10.1016/00167037(89)90036-7

Mejia L. M., Paytan A., Eisenhauer A., Bohm F., Kolevica A., Bolton C., Mendez-Vicente A., Abrevaya L., Isensee K. and Stoll H. (2018) Controls over $\delta^{44 / 40} \mathrm{Ca}$ and $\mathrm{Sr} / \mathrm{Ca}$ variations in coccoliths: new perspectives from laboratory cultures and cellular models. Earth and Planetary Science Letters. 481, 48-60.

McArthur, J.M., Howarth, R.J., Bailey, T.R., 2001. Strontium Isotope Stratigraphy: LOWESS Version 3: Best Fit to the Marine Sr-Isotope Curve for 0-509 Ma and Accompanying Look-up Table for Deriving Numerical Age. The Journal of Geology 109, 155-170. https://doi.org/10.1086/319243

Milliman, J.D., 1993. Production and accumulation of calcium carbonate in the ocean: Budget of a nonsteady state. Global Biogeochem. Cycles 7, 927-957. https://doi.org/10.1029/93GB02524

Moore, J., Jacobson, A.D., Holmden, C., Craw, D., 2013. Tracking the relationship between mountain uplift, silicate weathering, and long-term $\mathrm{CO} 2$ consumption with $\mathrm{Ca}$ isotopes:

Southern Alps, New Zealand. Chemical Geology 341, 110-127.

https://doi.org/10.1016/j.chemgeo.2013.01.005

Moynier, F., Fujii, T., 2017. Calcium isotope fractionation between aqueous compounds relevant to low-temperature geochemistry, biology and medicine. Sci Rep 7, 44255. https://doi.org/10.1038/srep44255 
Nägler, T.F., Eisenhauer, A., Müller, A., Hemleben, C., Kramers, J., 2000. The $\delta^{44}$ Ca-temperature calibration on fossil and cultured Globigerinoides sacculifer: New tool for reconstruction of past sea surface temperatures. Geochem. Geophys. Geosyst. 1, 1052. https://doi.org/10.1029/2000GC000091

Nägler, Th.F., Villa, I.M., 2000. In pursuit of the 40K branching ratios: K-Ca and 39Ar-40Ar dating of gem silicates. Chemical Geology 169, 5-16. https://doi.org/10.1016/S00092541(99)00194-1

Nelson, D.R., McCulloch, M.T., 1989. Petrogenetic applications of the ${ }^{40} \mathrm{~K}-{ }^{40} \mathrm{Ca}$ radiogenic decay scheme - A reconnaissance study. Chemical Geology 79, 275-293. https://doi.org/10.1016/0168-9622(89)90034-1

Nielsen, L.C., DePaolo, D.J., De Yoreo, J.J., 2012. Self-consistent ion-by-ion growth model for kinetic isotopic fractionation during calcite precipitation. Geochimica et Cosmochimica Acta 86, 166-181. https://doi.org/10.1016/j.gca.2012.02.009

Ockert, C., Gussone, N., Kaufhold, S., Teichert, B.M.A., 2013. Isotope fractionation during Ca exchange on clay minerals in a marine environment. Geochimica et Cosmochimica Acta 112, 374-388. https://doi.org/10.1016/j.gca.2012.09.041

Payne, J.L., Clapham, M.E., 2012. End-Permian Mass Extinction in the Oceans: An Ancient Analog for the Twenty-First Century? Annual Review of Earth and Planetary Sciences 40, 89111. https://doi.org/10.1146/annurev-earth-042711-105329

Payne, J.L., Turchyn, A.V., Paytan, A., DePaolo, D.J., Lehrmann, D.J., Yu, M., Wei, J., 2010. Calcium isotope constraints on the end-Permian mass extinction. PNAS 107, 8543-8548. https://doi.org/10.1073/pnas.0914065107

Pruss, S.B., Blättler, C.L., Macdonald, F.A., Higgins, J.A., 2018. Calcium isotope evidence that the earliest metazoan biomineralizers formed aragonite shells. Geology 46, 763-766. https://doi.org/10.1130/G45275.1

Reynard, L.M., Day, C.C., Henderson, G.M., 2011. Large fractionation of calcium isotopes during cave-analogue calcium carbonate growth. Geochimica et Cosmochimica Acta 75, 37263740. https://doi.org/10.1016/j.gca.2011.04.010

Richter, F.M., DePaolo, D.J., 1988. Diagenesis and Sr isotopic evolution of seawater using data from DSDP 590B and 575. Earth and Planetary Science Letters 90, 382-394. https://doi.org/10.1016/0012-821X(88)90137-9

Richter, F.M., DePaolo, D.J., 1987. Numerical models for diagenesis and the Neogene Sr isotopic evolution of seawater from DSDP Site 590B. Earth and Planetary Science Letters 83, $27-$ 38. https://doi.org/10.1016/0012-821X(87)90048-3

Richter, F.M., Liang, Y., 1993. The rate and consequence of Sr diagenesis in deep-sea carbonates. Earth and Planetary Science Letters 117, 553-565.

Ridgwell, A., Zeebe, R.E., 2005. The role of the global carbonate cycle in the regulation and evolution of the Earth system. Earth and Planetary Science Letters 234, 299-315. https://doi.org/10.1016/j.eps1.2005.03.006

Roberts, J., Kaczmarek, K., Langer, G., Skinner, L.C., Bijma, J., Bradbury, H., Turchyn, A.V., Lamy, F., Misra, S., 2018. Lithium isotopic composition of benthic foraminifera: A new proxy 
for paleo-pH reconstruction. Geochimica et Cosmochimica Acta, Chemistry of oceans past and present: A Special Issue in tribute to Harry Elderfield 236, 336-350. https://doi.org/10.1016/j.gca.2018.02.038

Rosenthal, Y., Boyle, E.A., Slowey, N., 1997. Temperature control on the incorporation of magnesium, strontium, fluorine, and cadmium into benthic foraminiferal shells from Little Bahama Bank: prospects for thermocline paleoceanography. Geochimica et Cosmochimica Acta 61, 3633-3643.

Rothman, D.H., Hayes, J.M., Summons, R.E., 2003. Dynamics of the Neoproterozoic carbon cycle. PNAS 100, 8124-8129. https://doi.org/10.1073/pnas.0832439100

Russell, W.A., Tombrello, T.A., Papanastassiou, D.A., 1978. Ca isotope fractionation on the Earth and other solar system materials. Geochimica et Cosmochimica Acta 42, 1075-1090.

Ryu, J.S., Jacobson, A.D., Holmden, C., Lundstrom, C., Zhang, Z., 2011. The major ion, $\delta^{44 / 40} \mathrm{Ca}, \delta^{44 / 42} \mathrm{Ca}$, and $\delta^{26} \mathrm{Mg}$ geochemistry of granite weathering at $\mathrm{pH}=1$ and $\mathrm{T}=25^{\circ} \mathrm{C}$ : power-law processes and the relative reactivity of minerals. Geochim. Cosmochim. Acta 75, 6004-6026.

Sawaki, Y., Tahata, M., Ohno, T., Komiya, T., Hirata, T., Maruyama, S., Han, J., Shu, D., 2014. The anomalous $\mathrm{Ca}$ cycle in the Ediacaran ocean: Evidence from $\mathrm{Ca}$ isotopes preserved in carbonates in the Three Gorges area, South China. Gondwana Research 25, 1070-1089. https://doi.org/10.1016/j.gr.2013.03.008

Schmitt, A.-D., Chabaux, F., Stille, P., 2003. The calcium riverine and hydrothermal isotopic fluxes and the oceanic calcium mass balance. Earth and Planetary Science Letters 213, 503518. https://doi.org/10.1016/S0012-821X(03)00341-8

Shao, Y., Farkaš, J., Holmden, C., Mosley, L., Kell-Duivestein, I., Izzo, C., Reis-Santos, P., Tyler, J., Törber, P., Frýda, J., Taylor, H., Haynes, D., Tibby, J., Gillanders, B.M., 2018. Calcium and strontium isotope systematics in the lagoon-estuarine environments of South Australia: Implications for water source mixing, carbonate fluxes and fish migration. Geochimica et Cosmochimica Acta 239, 90-108. https://doi.org/10.1016/j.gca.2018.07.036

Shih, C.-Y., Nyquist, L.E., Wiesmann, H., 1993. K-Ca chronology of lunar granites. Geochimica et Cosmochimica Acta 57, 4827-4841. https://doi.org/10.1016/0016-7037(93)902028

Silva-Tamayo, J.C., Lau, K.V., Jost, A.B., Payne, J.L., Wignall, P.B., Newton, R.J., Eisenhauer, A., Depaolo, D.J., Brown, S., Maher, K., Lehrmann, D.J., Altiner, D., Yu, M., Richoz, S., Paytan, A., 2018. Global perturbation of the marine calcium cycle during the Permian-Triassic transition. GSA Bulletin 130, 1323-1338. https://doi.org/10.1130/B31818.1

Silva-Tamayo, J.C., Nägler, T.F., Sial, A.N., Nogueira, A., Kyser, K., Riccomini, C., James, N.P., Narbonne, G.M., Villa, I.M., 2010. Global perturbation of the marine Ca isotopic composition in the aftermath of the Marinoan global glaciation. Precambrian Research, Precambrian Isotope Stratigraphy 182, 373-381. https://doi.org/10.1016/j.precamres.2010.06.015

Sime, N.G., De La Rocha, C.L., Galy, A., 2005. Negligible temperature dependence of calcium isotope fractionation in 12 species of planktonic foraminifera. Earth and Planetary Science Letters 232, 51-66. https://doi.org/10.1016/j.eps1.2005.01.011 
Sime, N.G., De La Rocha, C.L., Tipper, E.T., Tripati, A., Galy, A., Bickle, M.J., 2007. Interpreting the $\mathrm{Ca}$ isotope record of marine biogenic carbonates. Geochimica et Cosmochimica Acta 71, 3979-3989. https://doi.org/10.1016/j.gca.2007.06.009

Skulan, J., DePaolo, D.J., Owens, T.L., 1997. Biological control of calcium isotopic abundances in the global calcium cycle. Geochimica et Cosmochimica Acta 61, 2505-2510. https://doi.org/10.1016/S0016-7037(97)00047-1

Smith, S.V., Buddemeier, R.W., Redalje, R.C., Houck, J.E., 1979. Strontium-calcium thermometry in coral skeletons. Science 204, 404-407.

Soudry, D., Glenn, C.R., Nathan, Y., Segal, I., VonderHaar, D., 2006. Evolution of Tethyan phosphogenesis along the northern edges of the Arabian-African shield during the CretaceousEocene as deduced from temporal variations of $\mathrm{Ca}$ and $\mathrm{Nd}$ isotopes and rates of $\mathrm{P}$ accumulation. Earth-Science Reviews 78, 27-57. https://doi.org/10.1016/j.earscirev.2006.03.005

Stanley, S.M., 2006. Influence of seawater chemistry on biomineralization throughout phanerozoic time: Paleontological and experimental evidence. Palaeogeography, Palaeoclimatology, Palaeoecology 232, 214-236. https://doi.org/10.1016/j.palaeo.2005.12.010

Steiger, R.H., Jäger, E., 1977. Subcommission on geochronology: convention on the use of decay constants in geo- and cosmochronology. Earth Planet. Sci. Lett. 36, 359-362.

Steuber, T., Buhl, D., 2006. Calcium-isotope fractionation in selected modern and ancient marine carbonates. Geochimica et Cosmochimica Acta 70, 5507-5521. https://doi.org/10.1016/j.gca.2006.08.028

Stoll, H.M., Schrag, D.P., 1998. Effects of Quaternary Sea Level Cycles on Strontium in Seawater. Geochimica et Cosmochimica Acta 62, 1107-1118. https://doi.org/10.1016/S00167037(98)00042-8

Stoll, H.M., Schrag, D.P., 2000. Coccolith $\mathrm{Sr} / \mathrm{Ca}$ as a new indicator of coccolithophorid calcification and growth rate. Geochemistry, Geophysics, Geosystems 1. https://doi.org/10.1029/1999GC000015

Stoll, H.M., Schrag, D.P., 2001. Sr/Ca variations in Cretaceous carbonates: relation to productivity and sea level changes. Palaeogeography, Palaeoclimatology, Palaeoecology 168, 311336. https://doi.org/10.1016/S0031-0182(01)00205-X

Sun, X., Higgins, J., Turchyn, A.V., 2016. Diffusive cation fluxes in deep-sea sediments and insight into the global geochemical cycles of calcium, magnesium, sodium and potassium. Marine Geology 373, 64-77. https://doi.org/10.1016/j.margeo.2015.12.011

Swart, P.K., 2008. Global synchronous changes in the carbon isotopic composition of carbonate sediments unrelated to changes in the global carbon cycle. PNAS 105, 13741-13745. https://doi.org/10.1073/pnas.0802841105

Swart, P.K., Eberli, G., 2005. The nature of the $\delta^{13} \mathrm{C}$ of periplatform sediments: Implications for stratigraphy and the global carbon cycle. Sedimentary Geology, Sedimentology in the 21st Century - A Tribute to Wolfgang Schlager 175, 115-129. https://doi.org/10.1016/j.sedgeo.2004.12.029 
Tang, J., Köhler, S.J., Dietzel, M., 2008a. $\mathrm{Sr}^{2+} / \mathrm{Ca}^{2+}$ and ${ }^{44} \mathrm{Ca} /{ }^{40} \mathrm{Ca}$ fractionation during inorganic calcite formation: I. Sr incorporation. Geochimica et Cosmochimica Acta 72, 37183732. https://doi.org/10.1016/j.gca.2008.05.031

Tang, J., Dietzel, M., Böhm, F., Köhler, S.J., Eisenhauer, A., 2008b. $\mathrm{Sr}^{2+} / \mathrm{Ca}^{2+}$ and ${ }^{44} \mathrm{Ca} /{ }^{40} \mathrm{Ca}$ fractionation during inorganic calcite formation: II. Ca isotopes. Geochimica et Cosmochimica Acta 72, 3733-3745. https://doi.org/10.1016/j.gca.2008.05.033

Tang, J., Niedermayr, A., Köhler, S.J., Böhm, F., Kısakürek, B., Eisenhauer, A., Dietzel, M., 2012. $\mathrm{Sr}^{2+} / \mathrm{Ca}^{2+}$ and ${ }^{44} \mathrm{Ca} /{ }^{40} \mathrm{Ca}$ fractionation during inorganic calcite formation: III. Impact of salinity/ionic strength. Geochimica et Cosmochimica Acta 77, 432-443. https://doi.org/10.1016/j.gca.2011.10.039

Taubner, I., Böhm, F., Eisenhauer, A., Garbe-Schönberg, D., Erez, J., 2012. Uptake of alkaline earth metals in Alcyonarian spicules (Octocorallia). Geochimica et Cosmochimica Acta 84, 239-255. https://doi.org/10.1016/j.gca.2012.01.037

Teichert, B.M.A., Gussone, N., Eisenhauer, A., Bohrmann, G., 2005. Clathrites: Archives of near-seafloor pore-fluid evolution $\left(\delta^{44 / 40} \mathrm{Ca}, \delta^{13} \mathrm{C}, \delta^{18} \mathrm{O}\right)$ in gas hydrate environments. Geology 33, 213-216. https://doi.org/10.1130/G21317.1

Teichert, B.M.A., Gussone, N., Torres, M.E., 2009. Controls on calcium isotope fractionation in sedimentary porewaters. Earth and Planetary Science Letters 279, 373-382. https://doi.org/10.1016/j.epsl.2009.01.011

Teng, F.-Z., Dauphas, N., M. Watkins, J., 2017. Non-Traditional Stable Isotopes: Retrospective and Prospective. Reviews in Mineralogy and Geochemistry 82, 1-26. https://doi.org/10.2138/rmg.2017.82.1

Tipper, E.T., Galy, A., Bickle, M.J., 2006. Riverine evidence for a fractionated reservoir of Ca and $\mathrm{Mg}$ on the continents: implications for the oceanic Ca cycle. Earth Planet. Sci. Lett. 247, 267-279.

Tipper, E.T., Gaillardet, J., Galy, A., Louvat, P., Bickle, M.J., Capmas, F., 2010. Calcium isotope ratios in the world's largest rivers: A constraint on the maximum imbalance of oceanic calcium fluxes. Global Biogeochemical Cycles 24. https://doi.org/10.1029/2009GB003574

Tipper, E.T., Schmitt, Anne-Désirée, Gussone, N., 2016. Global Ca Cycles: Coupling of Continental and Oceanic Processes, in: Gussone, N., Schmitt, Anne-Desiree, Heuser, A., Wombacher, F., Dietzel, M., Tipper, E., Schiller, M. (Eds.), Calcium Stable Isotope Geochemistry, Advances in Isotope Geochemistry. Springer Berlin Heidelberg, Berlin, Heidelberg, pp. 173222. https://doi.org/10.1007/978-3-540-68953-9_6

Turchyn, A.V., DePaolo, D.J., 2011. Calcium isotope evidence for suppression of carbonate dissolution in carbonate-bearing organic-rich sediments. Geochimica et Cosmochimica Acta 75, 7081-7098. https://doi.org/10.1016/j.gca.2011.09.014

Tziperman, E., Halevy, I., Johnston, D.T., Knoll, A.H., Schrag, D.P., 2011. Biologically induced initiation of Neoproterozoic snowball-Earth events. Proc Natl Acad Sci U S A 108, 15091-15096. https://doi.org/10.1073/pnas.1016361108

Ullmann, C.V., Böhm, F., Rickaby, R.E.M., Wiechert, U., Korte, C., 2013. The Giant Pacific Oyster (Crassostrea gigas) as a modern analog for fossil ostreoids: Isotopic $(\mathrm{Ca}, \mathrm{O}, \mathrm{C})$ and 
elemental ( $\mathrm{Mg} / \mathrm{Ca}, \mathrm{Sr} / \mathrm{Ca}, \mathrm{Mn} / \mathrm{Ca})$ proxies. Geochemistry Geophysics Geosystems 14,4109 4120, https://doi.org/10.1002/ggge.20257.

Valdes, M.C., Bermingham, K.R., Huang, S., Simon, J.I., this issue. Calcium isotope cosmochemistry. Chemical Geology.

Veizer, J., Ala, D., Azmy, K., Bruckschen, P., Buhl, D., Bruhn, F., Carden, G.A.F., Diener, A., Ebneth, S., Godderis, Y., Jasper, T., Korte, C., Pawellek, F., Podlaha, O.G., Strauss, H., 1999. ${ }^{87} \mathrm{Sr} /{ }^{86} \mathrm{Sr}, \delta^{13} \mathrm{C}$ and $\delta^{18} \mathrm{O}$ evolution of Phanerozoic seawater. Chemical Geology 161, 59-88. https://doi.org/10.1016/S0009-2541(99)00081-9

von Allmen, K., Nägler, T.F., Pettke, T., Hippler, D., Griesshaber, E., Logan, A., Eisenhauer, A., Samankassou, E., 2010. Stable isotope profiles (Ca, O, C) through modern brachiopod shells of T. septentrionalis and G. vitreus: Implications for calcium isotope paleo-ocean chemistry. Chemical Geology 269, 210-219. https://doi.org/10.1016/j.chemgeo.2009.09.019

Wang, J., Jacobson, A. D., Zhang, H., Ramezani, J., Sageman, B. B., Hurtgen, M. T., Bowring, S. A., and Shen, S-Z. (2019) Coupled $\delta^{44 / 40} \mathrm{Ca},{ }^{87} \mathrm{Sr} /{ }^{86} \mathrm{Sr}$, and $\delta^{88 / 86} \mathrm{Sr}$ geochemistry across the end-Permian mass extinction event. Geochimica et Cosmochimica Acta. 262, 143-165.

Wang, S., Yan, W., Magalhães H.V., Chen, Z., Pinheiro, M. L., Gussone, N. (2012) Calcium isotope fractionation and its controlling factors over authigenic carbonates in the cold seeps of the northern South China Sea. Chinese Science Bulletin 57, 1325-1332.

Wang, S., Yan, W., Magalhães H.V., Chen, Z., Pinheiro, M.L., Gussone, N. (2014) Factors influencing methane-derived authigenic carbonate formation at cold seep from southwestern Dongsha area in the northern South China. Environmental Earth Sciences, DOI 10.1007/s12665-013-2611-9

Wei, G.-Y., Hood, A.v.S., Chen, X, Li D., Wei, W., Wen, B., Gong, Z., Yang, T., Zhang, Z.F., and Ling, H. F., 2019. Ca and Sr isotope constraints on the formation of the Marinoan cap dolostones. Earth and Planetary Science Letters. 511, 202-212.

Weinbauer, M.G., Velimirov, B., 1995. Calcium, Magnesium and strontium concentrations in the calcite sclerites of Mediterranean gorgonians (Coelenterata: Octocorallia). Estaurine and Coastal Shelf Sciences 40, 87-104.

Zhu, P., Macdougall, J.D., 1998. Calcium isotopes in the marine environment and the oceanic calcium cycle. Geochimica et Cosmochimica Acta 62, 1691-1698.

https://doi.org/10.1016/S0016-7037(98)00110-0

Figure captions:

Figure 1: Simplified model for the oceanic Ca budget. Main Ca sources of the ocean are displayed on the left side, while main sinks are plotted on the right. Some reservoirs may act as sources and sinks (indicated by arrows), e.g. re-dissolved carbonate sediments. 
1617 Figure 2: Range of $\delta^{44 / 40} \mathrm{Ca}$ values of different carbonate materials acting as main Ca sinks of 1618 the ocean.

1619 Carbonate $\delta^{44 / 40} \mathrm{Ca}$ values coloured by $\mathrm{Sr} / \mathrm{Ca}$ ratios from a range of synthetic and modern to Neogene sediments (grey is used for studies where Sr concentrations are not reported). For comparison with other materials, the synthetic carbonates are reported as their fractionation recalculated relative to modern seawater: (1) fractionation of inorganic aragonite from laboratory experiments (AlKhatib and Eisenhauer, 2017b; Dietzel et al., 2004; Gussone et al., 2003), (2) Modern skeletal calcite composed of bivalves, brachiopods, and molluscs (Farkaš et al., 2007b; Immenhauser et al., 2005; Steuber and Buhl, 2006), (3) platform aragonite surface sediments (bulk and ooids, Higgins et al., 2018), (4) Pelagic sediments ( 0-10 Myrs) composed of foraminiferas (Fantle, 2015; Fantle and DePaolo, 2007; Gussone and Heuser, 2016; Kisakürek et al., 2011), coccoliths (Gussone et al., 2007; Langer et al., 2007), and dinoflagellates (Gussone et al., 2010), (5) Modern biogenic skeletal aragonite corals (Chen et al., 2016; Gothmann et al., 2016; Inoue et al., 2015), (6) authigenic aragonite clathrites (Teichert et al., 2005), (7) highmagnesium calcite from Site 1131 (Higgins et al., 2018) and high-magnesium foraminifers (Gussone et al., 2016), (8) inorganic calcite from laboratory experiments with varying precipitation rates (AlKhatib and Eisenhauer, 2017a; Tang et al., 2008b; Lemarchand et al., 2004), (9) authigenic carbonates from the Miocene Monterey Formation and the northern South China Sea (Blättler et al., 2015; Wang et al., 2012; 2014), (10) Synthetic and natural ikarite (Gussone et al., 2011), (11) platform dolomites from the Great and Little Bahamas Bank (Ahm et al., 2018; Higgins et al., 2018), (12) Modern hardground carbonate cements from the Enewetak Atoll (Erhardt et al., this issue, Erhardt et al., in review). For comparison, dashed vertical lines indicate the $\delta^{44 / 40} \mathrm{Ca}$ values of Bulk Silicate Earth (BSE) and modern seawater (SW) and black triangles indicate the mean value and standard deviation for each group. 
1642 Figure 3: Scatterplots of $\delta^{44 / 40} \mathrm{Ca}$ vs. $\mathrm{Sr} / \mathrm{Ca}$ ratios for published bulk carbonate records.

1643

1644

1645

1646

1647

1648

1649

1650

1651

1652

1653

1654

1655

1656

1657

1658

1659

1660

1661

1662

1663

The $\mathrm{Sr} / \mathrm{Ca}$ ratios $(\mathrm{mmol} / \mathrm{mol})$ are shown on a linear scale in the left panel and on a logarithmic scale in the right panel. $\mathrm{Mg} / \mathrm{Ca}$ ratios are shown on a colour ramp, where blue symbols have higher $\mathrm{Mg} / \mathrm{Ca}$ and red symbols have lower $\mathrm{Mg} / \mathrm{Ca}$. Precambrian data from Husson et al. (2015), Blättler et al. (2017), Pruss et al. (2018), Ahm et al. (2019), Wei et al. (2019). Aragonite data from Jost et al. (2017, 2014), Lau et al. (2017), Silva-Tamayo et al. (2018), Wang et al. (2019). Calcite data from Holmden (2009), Griffith et al. (2015), Farkaš et al. (2016), Kimmig and Holmden (2017), Jones et al. (in press). The terms calcite sea and aragonite sea refer to periods in Earth history in which the chemical composition of the ocean water promoted precipitation of calcite and aragonite, respectively (e.g. Hardie 1996).

Figure 4: Comparison of different archives recording $\delta^{44 / 40} \mathrm{Ca}_{\text {seawater variation through time }}$

Most records suggest an increase in $\delta^{44 / 40} \mathrm{Ca}$ of the seawater from the Miocene towards the Holocene, but timing and magnitude of the variation differ. Because of the larger isotope fractionation, the barite records (Griffith et al. 2011, 2008a) are related to the secondary $\delta^{44 / 40} \mathrm{Ca}$ axis, which is offset by $1 \%$. The $\delta^{44 / 40} \mathrm{Ca}$ records of carbonate material, foraminifers from Heuser et al. (2005) and Sime et al. (2007) and bulk carbonate (Griffith et al. 2011: dotted), Fantle and DePaolo (2007: long dashed, 2005: short-dashed), including the data of De La Rocha and DePaolo (2000) is related to the primary y-axis. Marine phosphorites show an offset between peloidal phosphorites (Schmitt et al., 2003) and crusts (Arning et al., 2009) of about 0.5\%. Overall, records based on a limited number of taxa seem to show less scatter compared to bulk samples. 
1665 Figure 5: Approaches using the combined $\delta^{44 / 40} \mathrm{Ca}-\mathrm{Sr} / \mathrm{Ca}$ systematics to constrain the paleo 1666 seawater composition. A: The offset between inorganic calcite formed from modern seawater 1667 and ancient diagenetically overprinted calcite indicates the difference between modern and 1668 paleo $\delta^{44 / 40} \mathrm{Ca}_{\text {seawater }}$ (Tang et al. 2008b, Farkaš et al. 2016). B: Determination of paleo $1669 \delta^{44 / 40} \mathrm{Ca}_{\text {seawater }}$ and $\mathrm{Sr} / \mathrm{Ca}$ using the intercept of the fractionation arrays defined by ostracods 1670 and calcite cements or foraminifers (Gussone and Greifelt 2009).

1671

1672 Figure 6: Coupled $\mathrm{Ca}$ and $\mathrm{C}$ box model results.

1673 The predicted range in carbonate $\delta^{13} \mathrm{C}$, carbonate $\delta^{44 / 40} \mathrm{Ca}$, seawater $\delta^{44 / 40} \mathrm{Ca}$ (grey lines), and 1674 seawater omega $(\Omega)$ are shown for four different forcings, illustrated in the left hand panels: 1675 (A) an increase in volcanic degassing (solid line) and subsequent riverine Ca delivery (dashed 1676 line), (B) a shift to globally more prevalent aragonite precipitation, (C) increase in alkalinity, 1677 and (D) increase in the hydrothermal Ca flux. Note that the seawater and carbonate $\delta^{44 / 40} \mathrm{Ca}$ 1678 covary, except if there is a global shift in $\mathrm{CaCO}_{3}$ mineralogy (example B). Model is adapted 1679 from Jost et al. (2017) and Silva-Tamayo et al. (2018). 


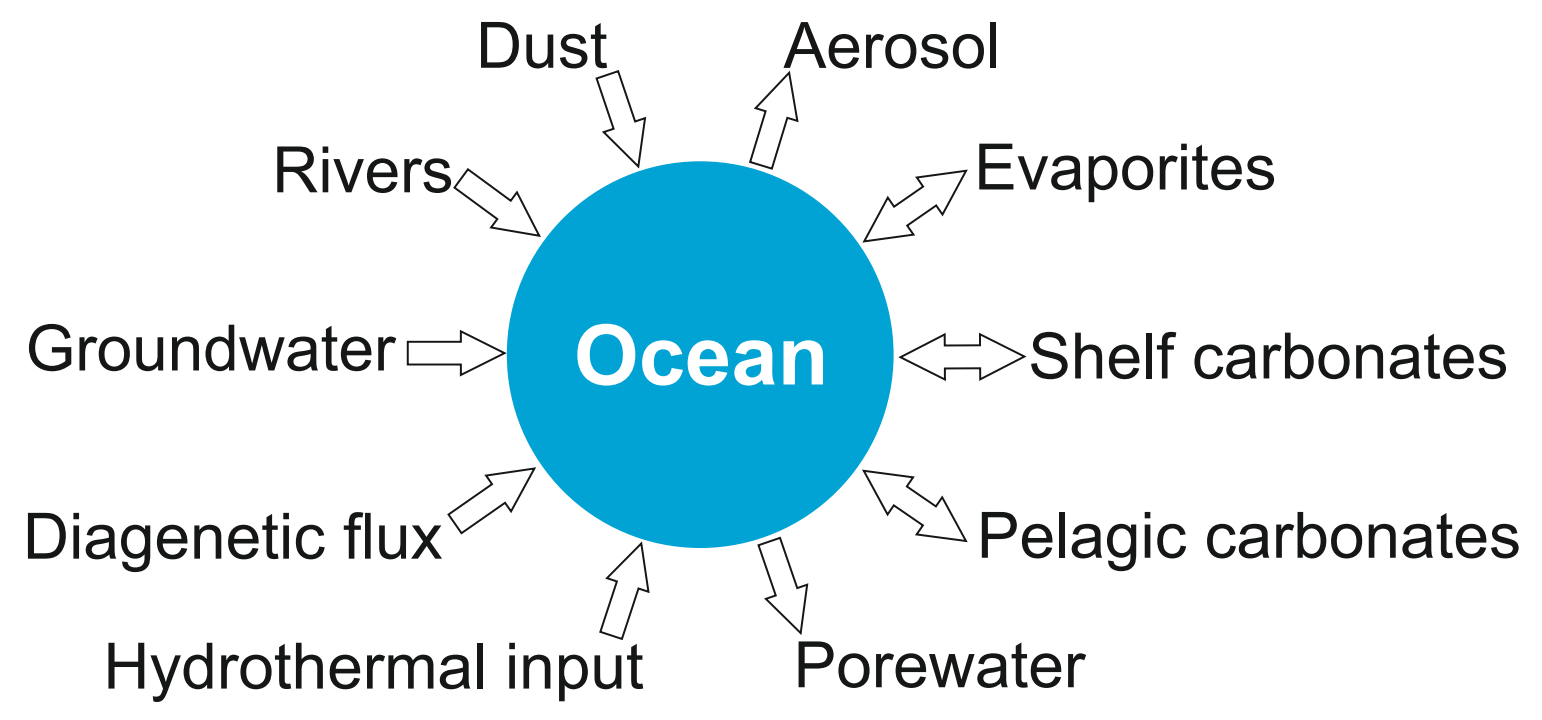

Figure 1 
Inorganic aragonite (laboratory)

$$
0.38 \pm 0.22(n=46)
$$

Skeletal Calcite (bivalves, brachiopods, molluscs)

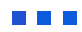

$$
0.39 \pm 0.38(n=38)
$$

Aragonite (Bahamas surface sediments)

$$
\stackrel{\Delta}{\Delta} 0.08(n=17)
$$

Pelagic ooze (forams, coccoliths, dinoflagellates)

$$
0.66 \pm 0.16(n=127)
$$

Skeletal Aragonite (corals)

$$
0.71 \pm 0.07(n=56)
$$

Aragonite clathrites

$\Delta$

$$
\stackrel{\Delta}{\Delta} \underset{0.73 \pm 0}{ }(\dot{n}=16)
$$

High-Mg calcite

$$
\frac{\Delta}{0.74 \pm 0.14(n=26)}
$$

Inorganic calcite (laboratory)

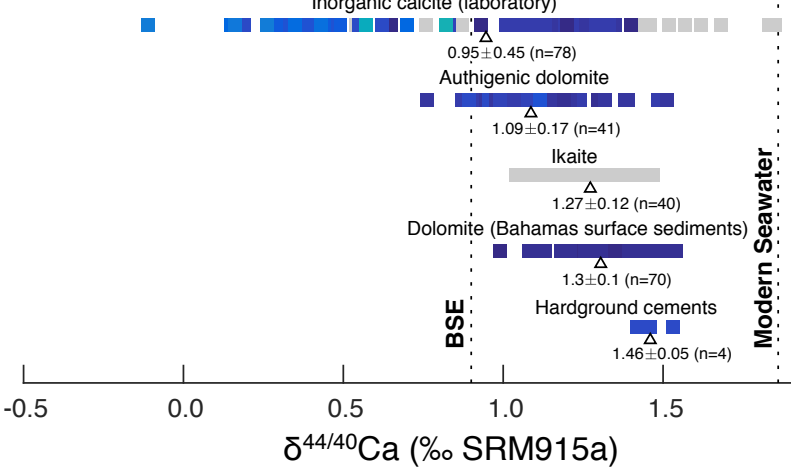



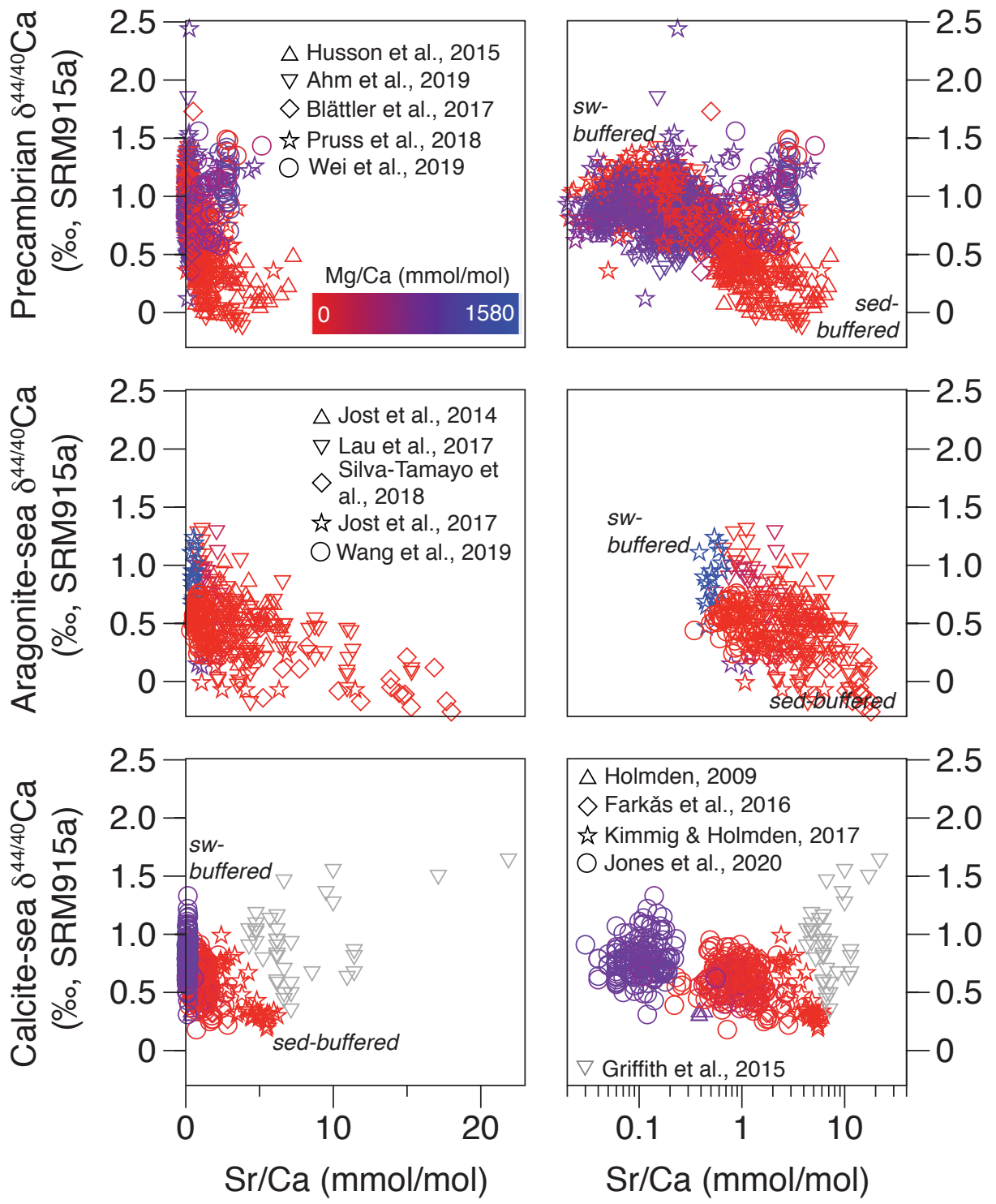


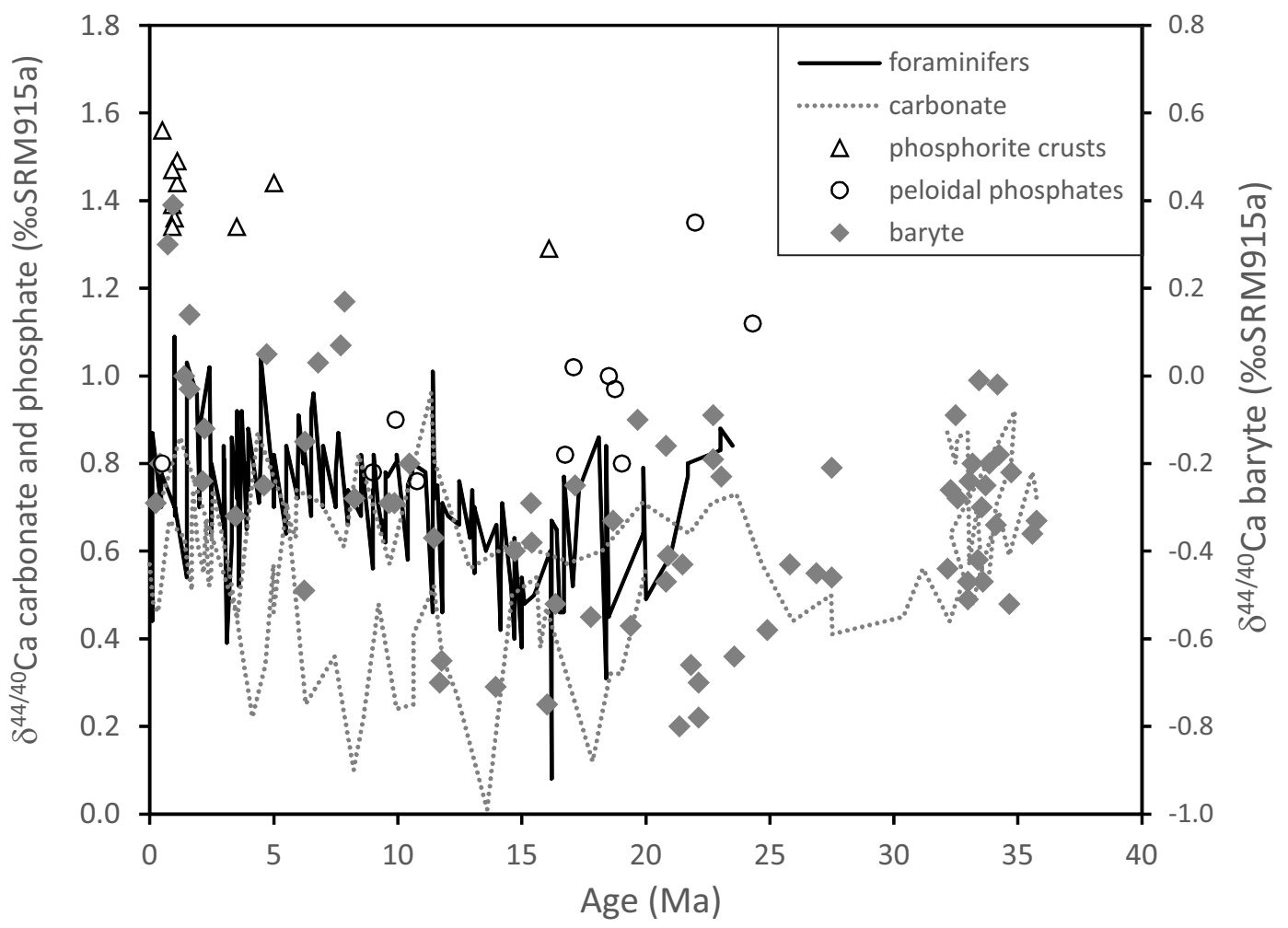

Figure 4 


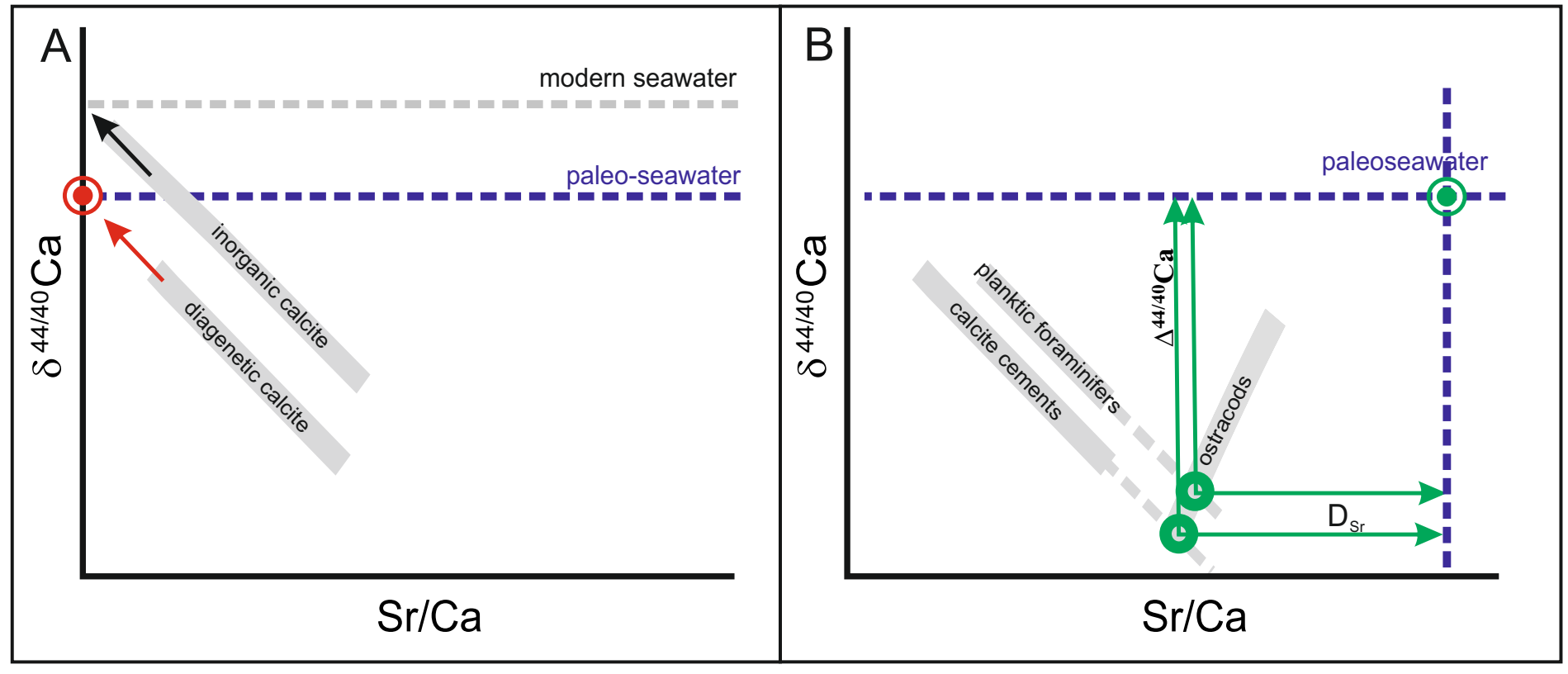

Figure 5 


\section{A Volcanism}

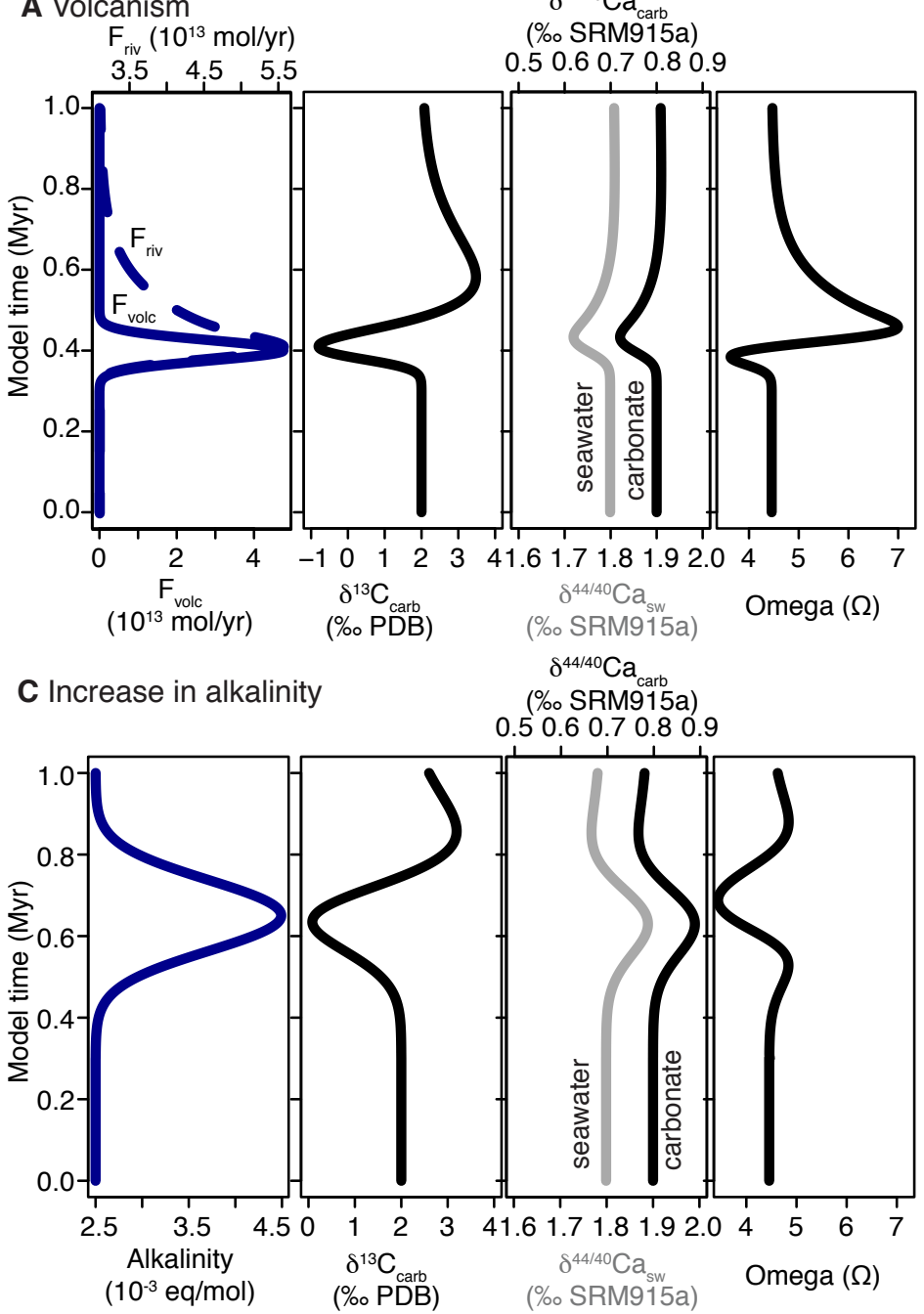

B Increase in aragonite

precipitation

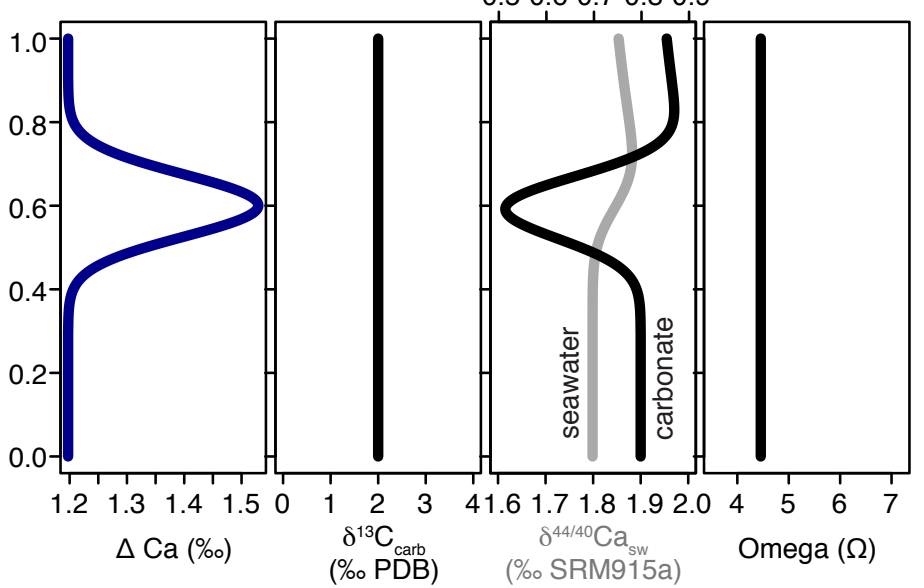

D Increase in hydrothermal flux

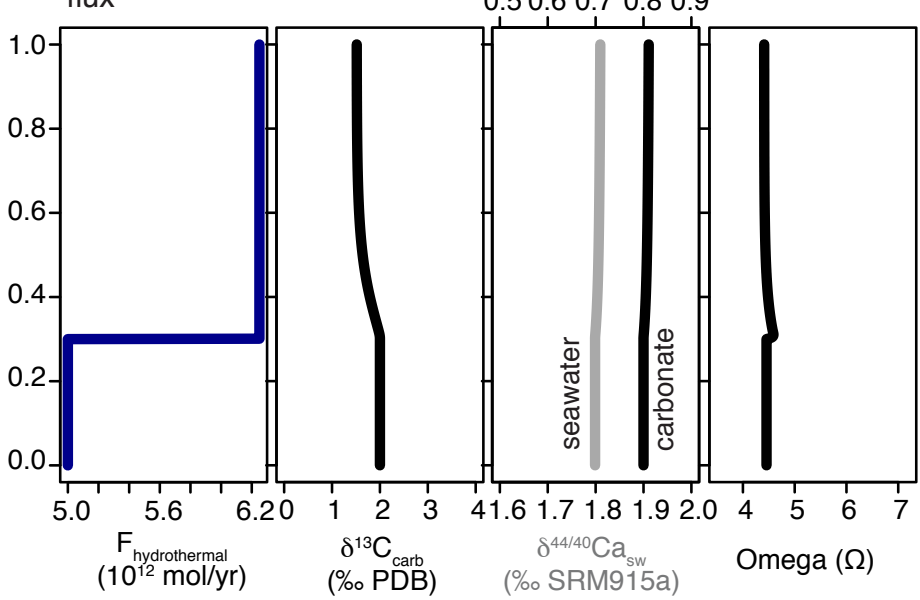

$\delta^{44 / 40} \mathrm{Ca}_{\text {carb }}$ (\% SRM915a) 0.50 .60 .70 .80 .9
(\% SRM915a)

0.50 .60 .70 .80 .9

(\%。 SRM915a) 